National Water-Quality Assessment Program

\title{
Trends in Suspended-Sediment Loads and Concentrations in the Mississippi River Basin, 1950-2009
}

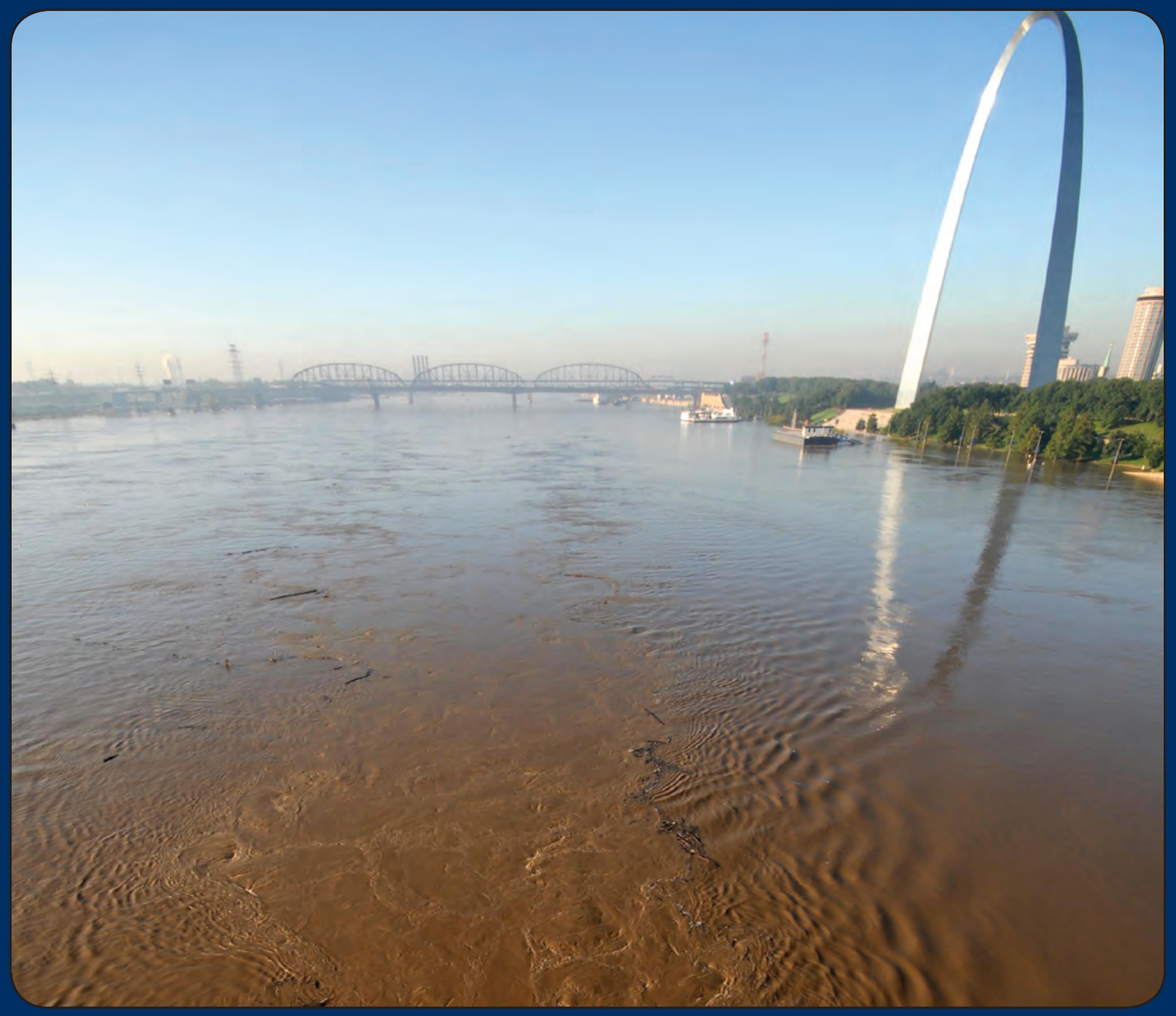

Scientific Investigations Report 2011-5200 
Cover photograph: U.S. Army Corps of Engineers Digital Visual Library (http://eportal.usace.army.mil/sites/DVL/default.aspx). 


\section{Trends in Suspended-Sediment Loads and Concentrations in the Mississippi River Basin, 1950-2009}

By David C. Heimann, Lori A. Sprague, and Dale W. Blevins

National Water-Quality Assessment Program

Scientific Investigations Report 2011-5200 


\title{
U.S. Department of the Interior \\ KEN SALAZAR, Secretary \\ U.S. Geological Survey \\ Marcia K. McNutt, Director
}

\author{
U.S. Geological Survey, Reston, Virginia: 2011
}

For more information on the USGS - the Federal source for science about the Earth, its natural and living resources, natural hazards, and the environment, visit http://www.usgs.gov or call 1-888-ASK-USGS.

For an overview of USGS information products, including maps, imagery, and publications, visit http://www.usgs.gov/pubprod

To order this and other USGS information products, visit http://store.usgs.gov

Any use of trade, product, or firm names is for descriptive purposes only and does not imply endorsement by the U.S. Government.

Although this report is in the public domain, permission must be secured from the individual copyright owners to reproduce any copyrighted materials contained within this report.

Suggested citation:

Heimann, D.C., Sprague, L.A., and Blevins, D.W., 2011, Trends in suspended-sediment loads and concentrations in the Mississippi River Basin, 1950-2009: U.S. Geological Survey Scientific Investigations Report 2011-5200, 33 p. 


\section{Contents}

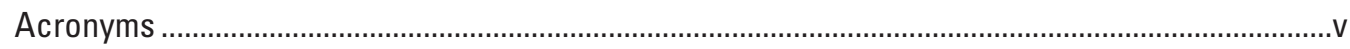

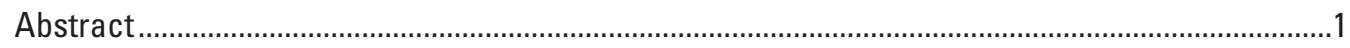

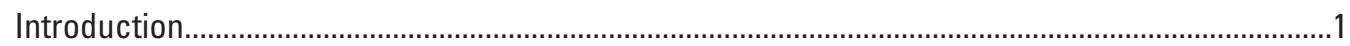

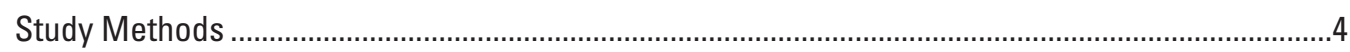

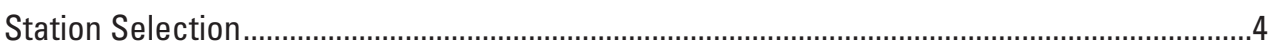

Determination of Annual Suspended-Sediment Loads ............................................................5

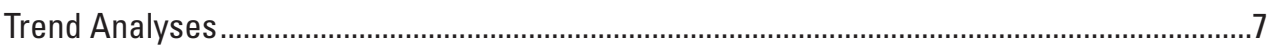

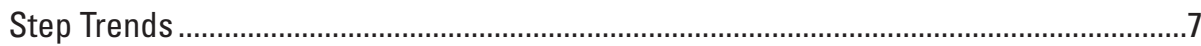

Monotonic Trends and Qualitative Temporal Variations in Suspended-Sediment Loads, Concentrations, and Streamflow ..........................................................8

Suspended-Sediment Trends in the Mississippi River Basin .............................................................8

Relative Sediment Contributions from Mississippi River Subbasins .........................................8

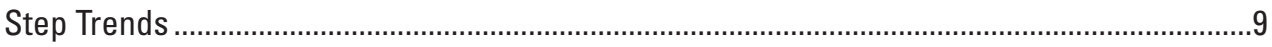

Monotonic Trends and Qualitative Temporal Relations ........................................................12

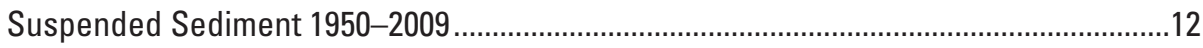

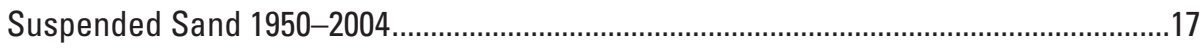

Suspended Sediment 1976-2009 .................................................................................

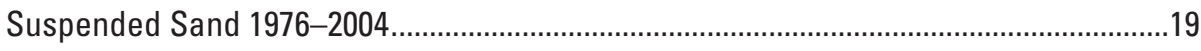

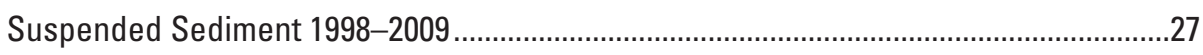

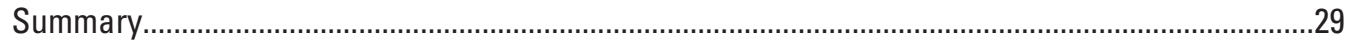

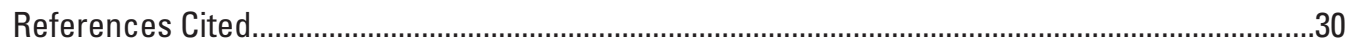

\section{Figures}

1. Map showing Mississippi River Basin, major subbasins, and U.S. Geological Survey streamgaging and sediment stations included in study.....................................................

2. Graph showing annual suspended-sediment loads of the Missouri, Ohio, upper Mississippi, and Arkansas Rivers, 1976-2009......

3. Maps and graphs showing summary of trends in annual suspended-sediment loads, flow-weighted concentrations, and streamflows at selected U.S. Geological Survey streamgaging stations in the Mississippi River Basin, 1950-2009 .

4. Graphs showing summary of temporal variations in flow-adjusted concentrations for selected U.S. Geological Survey streamgaging stations in the Mississippi River Basin, 1950-2009.

5. Graphs showing summary of temporal variations in annual suspended-sand loads and annual sand as a percentage of total suspended-sediment loads, 1950-2004........18

6. Graphs showing summary of temporal variations in flow-adjusted sand concentrations, 1950-2004 and 1976-2004

7. Maps and graphs showing summary of trends in annual suspended-sediment loads, flow-weighted concentrations, and streamflows at selected U.S. Geological Survey streamgaging stations in the Mississippi River Basin, 1976-2009.....

8. Map and graphs showing summary of temporal variations in flow-adjusted sediment concentrations for selected U.S. Geological Survey streamgaging stations in the Mississippi River Basin, 1976-2009 
9. Maps and graphs showing summary of trends in annual suspended-sediment loads, flow-weighted concentrations, and streamflows at selected U.S. Geological Survey streamgaging stations in the Mississippi River Basin, 1998-2009 ..

10. Map and graphs showing summary of temporal variations in flow-adjusted sediment concentrations for selected U.S. Geological Survey streamgaging stations in the Mississippi River Basin, 1998-2009

\section{Tables}

1. Main-stem reservoirs of the upper Missouri River Basin.

2. U.S. Geological Survey streamgaging stations in the Mississippi River Basin used in study.

3. Summary of contributions of suspended-sediment load from gaged tributaries to major subbasins of the lower Mississippi River Basin

4. Median annual suspended-sand loads at selected Missouri River Basin streamgaging stations, 1981-91.

5. Summary of step-trend analyses of suspended-sediment characteristics and streamflows for pre- (pre-1953) and post-Missouri River main-stem impoundment (post-1967)

periods at selected Missouri River and lower Mississippi River Basin stations

6. Summary of analyses of monotonic trends in annual suspended-sediment loads, flow weighted concentrations, and streamflows between 1950 and 2009 at selected Mississippi River Basin streamgaging stations.

7. Summary of analyses of monotonic trends in annual suspended-sand loads, flowweighted suspended-sand concentrations, and sand load as a percentage of total suspended-sediment load between 1950 and 2004 at selected Missouri River and lower Mississippi River Basin stations

8. Summary of analyses of monotonic trends in annual suspended-sediment loads, flowweighted concentrations, and streamflows between 1976 and 2009 at selected Mississippi River Basin streamgaging stations.

9. Summary of analyses of monotonic trends in annual suspended-sand loads, flowweighted suspended-sand concentrations, and suspended-sand load as a percentage of total suspended-sediment loads between 1976 and 2004 at selected Missouri River and lower Mississippi River Basin stations

10. Summary of analyses of monotonic trends in annual suspended-sediment loads, flowweighted suspended-sediment concentrations, and streamflows between 1998 and 2009 at selected Mississippi River Basin streamgaging stations. 


\section{Conversion Factors}

SI to Inch/Pound

\begin{tabular}{lcl}
\hline \multicolumn{1}{c}{ Multiply } & By & \multicolumn{1}{c}{ To obtain } \\
\hline millimeter $(\mathrm{mm})$ & Length & inch (in.) \\
kilometer $(\mathrm{km})$ & 0.03937 & mile $(\mathrm{mi})$ \\
\hline \multicolumn{3}{c}{ Area } \\
\hline square kilometer $\left(\mathrm{km}^{2}\right)$ & 0.62137 & square mile $\left(\mathrm{mi}^{2}\right)$ \\
hectare-meter $(\mathrm{ha}-\mathrm{m})$ & 0.38610 & acre-feet $(\mathrm{ac}-\mathrm{ft})$ \\
\hline & 8.1071 & \\
\hline liter $(\mathrm{L})$ & Volume & gallon $(\mathrm{gal})$ \\
\hline & 0.26417 & \\
\hline cubic meter per second $\left(\mathrm{m}^{3} / \mathrm{s}\right)$ & Flow rate & cubic feet per second $\left(\mathrm{ft}^{3} / \mathrm{s}\right)$ \\
\hline & 35.3147 & ton, short $(2,000 \mathrm{lb})$ \\
\hline metric ton $(\mathrm{t})$ & Mass & \\
\hline
\end{tabular}

\section{Acronyms}

FA SSC flow-adjusted suspended-sediment concentration (the positive and negative residuals of a linear regression model constructed from streamflow and suspended-sediment concentration data pairs, expressed in milligrams per liter)

FA SSDC flow-adjusted suspended-sand concentration (the positive and negative residuals of a linear regression model constructed from streamflow and suspended-sand concentration data pairs, expressed in milligrams per liter)

FW SCC flow-weighted suspended-sediment concentration (computed as the daily suspended-sediment load divided by the corresponding daily mean streamflow)

FW SSDC flow-weighted suspended-sand concentration (computed as the daily suspended-sand load divided by the corresponding daily mean streamflow)

SSC suspended-sediment concentration

SSDC suspended-sand concentration

SSDL suspended-sand loads

SSL suspended-sediment loads 



\title{
Trends in Suspended-Sediment Loads and Concentrations in the Mississippi River Basin, 1950-2009
}

\author{
By David C. Heimann, Lori A. Sprague, and Dale W. Blevins
}

\section{Abstract}

Trends in loads and concentrations of suspended sediment and suspended sand generally were downward for stations within the Mississippi River Basin during the 60-, 34-, and 12-year periods analyzed. Sediment transport in the lower Mississippi River has historically been, and continues to be, most closely correlative to sediment contributions from the Missouri River, which generally carried the largest annual suspended-sediment load of the major Mississippi River subbasins. The closure of Fort Randall Dam in the upper Missouri River in 1952 was the single largest event in the recorded historical decline of suspended-sediment loads in the Mississippi River Basin. Impoundments on tributaries and sediment reductions as a result of implementation of agricultural conservation practices throughout the basin likely account for much of the remaining Mississippi River sediment transport decline. Scour of the main-stem channel downstream from the upper Missouri River impoundments is likely the largest source of suspended sand in the lower Missouri River. The Ohio River was second to the Missouri River in terms of sediment contributions, followed by the upper Mississippi and Arkansas Rivers. Declines in sediment loads and concentrations continued through the most recent analysis period (1998-2009) at available Mississippi River Basin stations. Analyses of flowadjusted concentrations of suspended sediment indicate the recent downward temporal changes generally can be explained by corresponding decreases in streamflows.

\section{Introduction}

Suspended-sediment concentrations (SSCs) were first recorded in the Mississippi River Basin in 1804 along the Missouri River by William Clark during the Lewis and Clark Expedition (Moulton, 1986; Blevins, 2006), and in 1838 near the mouth of the Mississippi River by Andrew Talcott (U.S. Army Corp of Engineers, 1930; Keown and others, 1981). Monitoring of sediment transport within the Mississippi River Basin has continued through the present day (2011), which has led to an increasingly better understanding of its role and importance in the geomorphic and ecological integrity of the river channels and riparian resources throughout the basin.

Present-day suspended-sediment loads (SSLs) of the Mississippi River delivered to the Gulf of Mexico are about onehalf of the pre-1950s loads (Tuttle and Comb, 1981; Keown and others, 1986; Meade and Parker, 1985; Meade, 1995). This reduced Mississippi River sediment transport has been attributed to impoundments, implementation of soil conservation practices, and bank-stabilization efforts that have reduced contributions from the Missouri River Basin (Keown and others, 1981; Tuttle and Combe, 1981; Kesel, 1988; Meade and Moody, 2010), but other possible causes of the reductions include numerous engineering structures and channel modifications in the Mississippi River (Keown and others, 1981; Keown and others, 1986; Smith and Winkley, 1996; Biedenharn and others, 2000).

Substantial State and Federal funds have been spent to address multiple concerns resulting from the reduced SSLs in the Missouri and Mississippi River Basins, yet funds also are spent to reduce soil erosion and limit contributions of sediment to the Missouri and Mississippi Rivers. Reductions in SSLs in the Missouri River have lead to bed degradation in long reaches of the lower part of the river, which, in turn, has had large economic effects owing from the necessary alterations of river structures, increased pumping costs for water requirements, and modifications to aggregate mining operations (United States Army Corp of Engineers, 2009a) along with adverse effects on aquatic and riparian habitat (U.S. Fish and Wildlife, 2003). Reduced sediment transport from the Mississippi River Basin is cited as a factor in the loss of coastal wetlands in Louisiana (Kesel, 1988, 1989; van Heerden and DeRouen, 1997). Sediment transport is an important factor in assessing opportunities and constraints of several large-scale ecosystem restoration programs within the Mississippi River Basin including the Louisiana Coastal Area Restoration Program (U.S. Army Corps of Engineers, Louisiana Coastal Area Restoration Program, accessed August 2010, http://www.lca.gov/.), Missouri River Recovery Program (U.S. Army Corps of Engineers, Missouri River Recovery Program, accessed November 2010, http://www.moriverrecovery.org/ mrrp/f? $p=136: 1: 1186003470123021$ ), and Upper Mississippi River Environmental Management Program (U.S. Army Corps of Engineers, Upper Mississippi River Environmental 
Management Program, accessed November 2010, http://www. mvp.usace.army.mil/environment/default.asp? pageid=74). At the same time, sediment transport is closely associated with nutrient transport and the reduction of nutrient transport in the Mississippi River Basin to mitigate hypoxia (dissolved oxygen reductions) in the northern Gulf of Mexico is an objective of current State and Federal programs, including the Mississippi River Basin Healthy Watersheds Initiative (National Resources Conservation Service, Mississippi River Basin Healthy Watersheds Initiative, accessed November 12, 2010, http://www. nrcs.usda.gov/wps/portal/nrcs/detailfull/national/programs/ farmbill/initiatives/?\&cid=nrcsdev11_024120). Quantifying sediment and nutrient transport is a means of assessing the effectiveness of erosion control and conservation practices at multiple scales. Therefore, information on the spatial and temporal variability in the quantity of sediment transport at locations throughout the Mississippi River Basin is necessary to assess the feasibility of management alternatives of multiple local, State, and Federal interests.

Concerns related to sediment transport in the Mississippi River Basin and the need for an assessment of that transport prompted a study, as described in this report, of the changes in SSLs and SSCs at selected stations throughout the Mississippi River Basin and analyses of the relative contributions of sediment from the major subbasins. The Mississippi River Basin (fig. 1) is the largest river basin in the United States (U.S.) [3.21 million square kilometers $\left(\mathrm{km}^{2}\right)$ ] draining 41 percent of the conterminous United States. The Mississippi River transports more sediment than any other river in North America (Meade and others, 1990). The river extends 3,700 km from its headwaters in northern Minnesota to the mouth at the Gulf of Mexico. The upper Mississippi River main stem (upstream from the junction of the Mississippi River with the Ohio River near Cairo, Illinois) has been substantially altered by the construction of 29 navigation locks and dams between Minneapolis, Minnesota and Saint Louis, Missouri, most of which were completed during the 1930s (O'Brien and others, 1992; Knox, 2007). A primary tributary to the upper Mississippi River, the Illinois River/Illinois Waterway, has eight locks and dams that were constructed by 1933 between Chicago and the junction of the Illinois River with the Mississippi River at Grafton, Illinois (West Consultants Inc., 2000).

The lower Mississippi River was modified by bank stabilization, levees, meander cutoffs, and channel constrictions between 1930 and 1955 (Smith and Winkley, 1996). About
58 percent of the total Mississippi River Basin is regulated by hundreds of reservoirs (Tuttle and Combe, 1981). In 1963, the U.S. Army Corps of Engineers (USACE) completed a flowcontrol structure on the lower Mississippi River that controls flows between the Mississippi River and the Atchafalaya River through the Old River Outflow Channel (Mossa, 1996). The diversion maintains the flow in the Atchafalaya River at about 30 percent of the combined Mississippi and Red River flows. Total sediment transport from the Mississippi River Basin is, therefore, measured as the combined SSLs of the Mississippi and Atchafalaya Rivers.

Major tributaries to the lower Mississippi River include the Missouri (44.6 percent of contributing area), upper Mississippi (16.5 percent), Arkansas (15.4 percent), and Ohio (15.2 percent) Rivers (Knox, 2007). The lower Mississippi River receives a disproportionately large influx of sediment from the Missouri River and a disproportionately large contribution of its flow from the Ohio River (Meade, 1995; Knox, 2007).

The Missouri River Basin is the largest tributary to the Mississippi River Basin and the second largest river basin in the United States draining about one-sixth of the conterminous United States (1.37 million $\mathrm{km}^{2}$ ). The Missouri River is $3,770 \mathrm{~km}$ long from its headwaters in western Montana to its mouth at Saint Louis, Missouri, which also makes it the longest river in the United States. Bank stabilization and channel modifications to the Missouri River, associated with the Bank Stabilization and Navigation Project (BSNP), began in earnest in the 1930s and continued through the 1980s (U.S. Army Corp of Engineers, 2009a). Six major impoundments that regulate the flow from 53 percent of the basin area upstream from Saint Louis, Missouri also were constructed in the upper Missouri River (upstream from Yankton, South Dakota) between the beginning of construction in 1933 and the filling of the last impoundment in 1966 (table 1). These engineered modifications, along with land-use changes including changes in agricultural practices, and other engineered structures in the lower Mississippi River (meander cutoffs, river-training structures, bank revetments) have resulted in a reported 70 percent decline in sediment transported by the Missouri River to the Mississippi River (Meade and Moody, 2010) since the early $1950 \mathrm{~s}$.

The principal tributaries to the Missouri River include the Yellowstone, Platte (Nebraska), and Kansas Rivers. The Yellowstone River, the largest tributary to the Missouri in terms

Table 1. Main-stem reservoirs of the upper Missouri River Basin.

[Table modified from National Research Council, 2011]

\begin{tabular}{llcccc}
\hline \multicolumn{1}{c}{ Reservoir } & \multicolumn{1}{c}{ Dam } & Year started & Year closed & $\begin{array}{c}\text { Year } \\
\text { completed }\end{array}$ & $\begin{array}{c}\text { Storage } \\
\text { (hectare meter) }\end{array}$ \\
\hline Fort Peck & Fort Peck & 1933 & 1937 & 1940 & $1,210,000$ \\
Sakakawea & Garrison & 1946 & 1953 & 1954 & $2,840,000$ \\
Oahe & Oahe & 1948 & 1958 & 1962 & $2,900,000$ \\
Sharpe & Big Bend & 1959 & 1963 & 1966 & 234,000 \\
Francis Case & Fort Randall & 1946 & 1952 & 1953 & 678,000 \\
Lewis and Clark & Gavins Point & 1952 & 1955 & 1957 & 60,700 \\
\hline
\end{tabular}




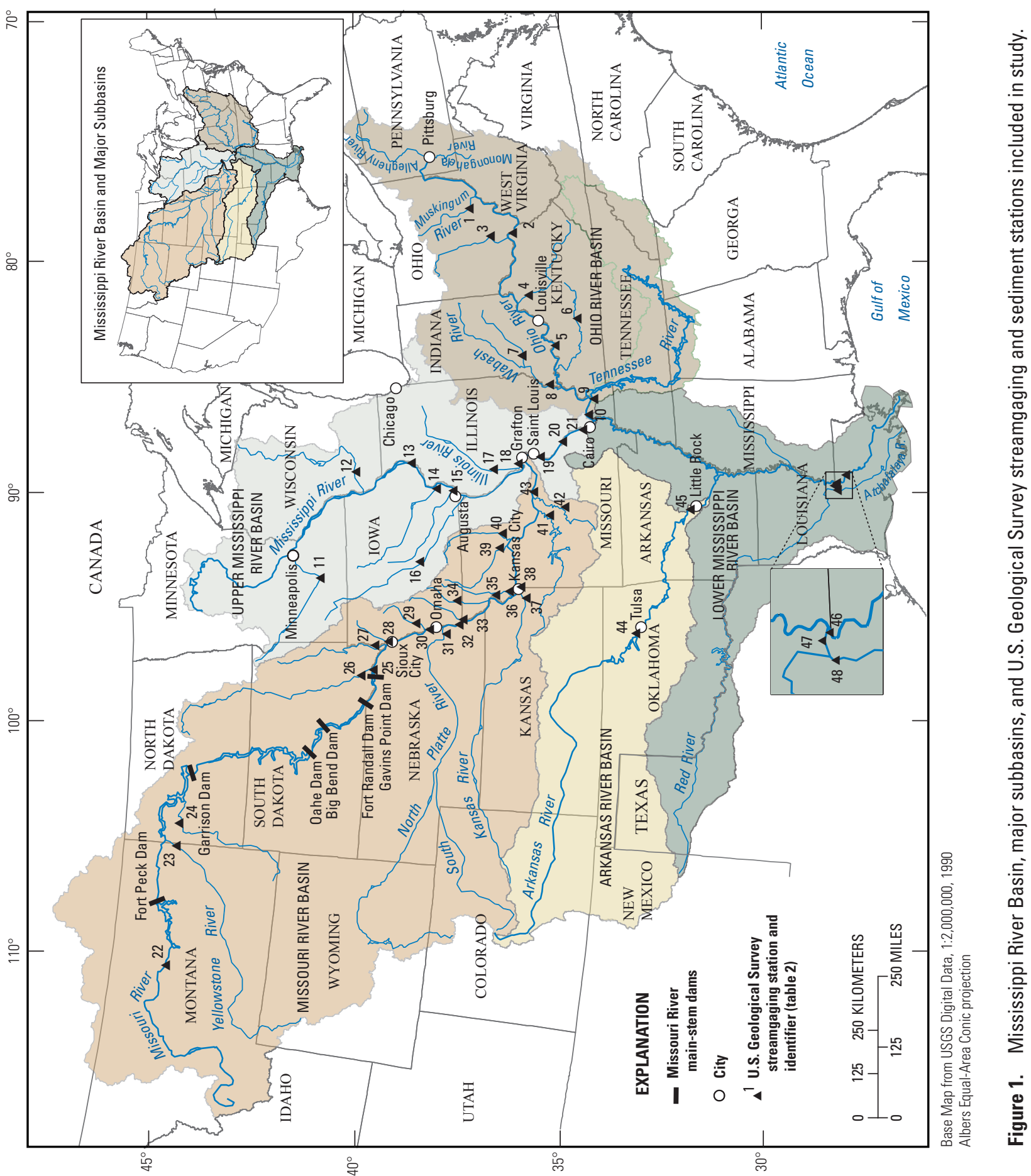


of discharge (Missouri Basin Inter-Agency Committee, 1969), with a drainage area of $182,000 \mathrm{~km}^{2}$, flows through Wyoming and Montana before it joins the Missouri River in western North Dakota. The lack of reservoirs on the Yellowstone River main stem makes it one of the longest free-flowing rivers in the United States. Hundreds of small impoundments, however, have been built on major tributaries (Zelt and others, 1999) of the Yellowstone River that were constructed for water supply, recreation, energy production, and flood control purposes. The Platte River originates in Colorado and Wyoming and flows eastward through Nebraska draining 230,000 $\mathrm{km}^{2}$ (Galat and others, 2005). Beginning in the early 1900s, many impoundments were built on the North and South Platte Rivers for public supply and irrigation. The Kansas River Basin is about $159,000 \mathrm{~km}^{2}$ and drains parts of Colorado, Nebraska, and Kansas. Eighteen Federal reservoirs have been constructed in the Kansas River Basin beginning in 1946, with 7 of the 18 completed by 1953 . Present-day impoundments on the major tributaries of the Kansas River and regulate about 85 percent of the flow from the basin (Perry, 1994).

The Arkansas River, the third largest tributary to the Mississippi River, drains an area of 505,000 $\mathrm{km}^{2}$. Reservoir and flood control projects on the Arkansas began in the late 1930s and modifications continued with the construction of 18 navigation locks and dams in the McClellan-Kerr Arkansas River Navigation System between 1967 and 2004 (17 of 18 were complete by 1970; The Encyclopedia of Arkansas History and Culture, McClellan-Kerr Arkansas River Navigation System (MKARNS) accessed June 2010, http:// encyclopediaofarkansas.net/encyclopedia/entry-detail.

aspx? entryID=2309). More than 40 large reservoirs were constructed between 1936 and the late 1960s within the Arkansas River Basin in Colorado, Kansas, Oklahoma, and Arkansas. Most of the major reservoirs on the lower Arkansas River in Oklahoma that reinforce the McClellan-Kerr Navigation System were completed by 1964 .

The Ohio River is formed at the junction of the Allegheny and Monongahela Rivers at Pittsburgh, Pennsylvania, and is $1,580 \mathrm{~km}$ long to its mouth at the Mississippi River near Cairo, Illinois. The Ohio River Basin is the smallest of the four major lower Mississippi River contributing subbasins in terms of area, $490,000 \mathrm{~km}^{2}$, but the largest in terms of contributing flow volume (Knox, 2007). A concrete lock and dam system for navigation has been in place on the Ohio River since the 1950s (Meade, 2004), and currently (2010) there are 21 locks and dams. Eighty-three reservoirs, about 95 major local floodprotection projects, and numerous small flood-control projects have been built on tributaries in the basin. Construction of the reservoirs and flood-control projects began in the late 1930s and most were completed by the 1950s (U.S. Army Corp of Engineers, 2009b).

The Tennessee River is the largest tributary of the Ohio River with a basin area of $106,000 \mathrm{~km}^{2}$ (White and others, 2005). The river is regulated by numerous impoundments including nine main-stem dams operated by the Tennessee
Valley Authority that were completed between 1913 and 1967, although most were completed by the mid-1940s.

The Wabash River is the second largest tributary to the Ohio River $\left(85,340 \mathrm{~km}^{2}\right)$, and whereas the upper $103 \mathrm{~km}$ has been regulated by a Corps of Engineers reservoir since 1968, the lower $661 \mathrm{~km}$ is the longest stretch of free-flowing river east of the Mississippi River (Karns and others, 2006). Despite the free-flowing status of the lower Wabash River main stem, Pyron and Neumann (2008) note that the hydrology of the river has been substantially altered by the construction of reservoirs and by land-cover changes within the basin during the past century.

Assessments of changes in water-quality constituents over time are a primary goal of the U.S. Geological Survey's (USGS) National Water-Quality Assessment (NAWQA) program (Gilliom and others, 2001). Previous studies have documented analyses of suspended-sediment trends in the Missouri (Sprague and others, 2006), upper Mississippi and Ohio (Lorenz and others, 2009), Tennessee (Hoos and others, 2000) and lower Mississippi and Atchafalaya Rivers (Rebich and Demcheck, 2007) for various periods between 1974 and 2004. Horowitz (2010) also examined trends in SSLs and flow-weighted (FW) SSCs at selected USGS streamgaging stations in the Mississippi River Basin for the 1981-2007 period.

The primary objective of the study described here, and the purpose of this report is to augment existing information by computing the relative sediment contributions from Mississippi River subbasins and determine temporal trends in streamflow, suspended sediment loads and concentrations at multiple Mississippi River main-stem and tributary stations, and for multiple time scales. The sediment contributions and trends in sediment contributions from subbasins could then be used to determine which tributaries, subbasins, or regions affect recent suspended-sediment trends near the mouth of the Mississippi River and in large receiving rivers such as the Missouri.

\section{Study Methods}

\section{Station Selection}

Station selection began with an assessment of published SSLs or SSCs and daily streamflow data at USGS streamgaging stations within the major subbasins of the Mississippi River Basin. The USGS National Water Information System (NWIS) database (http://waterdata.usgs.gov/nwis) was searched for main-stem and primary tributary stream stations with a drainage area of at least $2,500 \mathrm{~km}^{2}$ and for which daily sediment loads or discrete sediment concentrations and concurrent daily streamflow record of at least 10 years were available. Further selection criteria for those stations with sediment loads that were not already determined included selecting stations with SSC and suspended-sand concentration (SSDC) samples distributed throughout the water year (Oct. 1 to 
Sept. 30) and over the range of observed streamflows. At a minimum, the most downstream station with adequate suspended-sediment record from each major subbasin of the Mississippi River Basin (fig. 1) was selected for trend analyses.

Impoundments on the upper main stem of the Missouri River have had a substantial effect on sediment transport in the lower Missouri and Mississippi River downstream from Saint Louis, Missouri. To conduct step-trend analyses to assess changes in sediment transport in main-stem and tributary stations between pre- and post-impoundment periods, available stations with continuous or non-continuous sediment record spanning both periods were selected for analysis. As in previous studies (Keown and others, 1986; Jacobson and others, 2009) the pre-impoundment period in this study was defined as pre-1953 - before the closure of the downstream Fort Randall Dam. The post-impoundment period was defined as post-1967-after the last completed reservoir, Lake Sharpe (impounded by Big Bend Dam), was filled.

Final station selection and trend analysis periods were determined by maximizing the number of stations within multiple, selected analysis periods based on record availability. Stations were selected from the Missouri, upper Mississippi, Ohio, Arkansas, lower Mississippi, and Atchafalaya River Basins as shown in figure 1 and table 2 for trend analysis periods encompassing the last 60 years (1950-2009), the last 34 years (1976-2009), and the last 12 years (1998-2009) of available record. The multiple time periods used in trend analysis also provide a long-term context within which to view the more recent changes in streamflows and in the concentrations and loads of suspended sediment.

\section{Determination of Annual Suspended-Sediment Loads}

Annual SSLs and SSDLs described in this report refer to the suspended portion of transported sediment, and, therefore, do not include bedload. Bedload in large, low gradient rivers has been estimated to range from less than 5 percent (Holmes, 1996; Nittrouer and others, 2008) to 8 percent (Gaeuman and Jacobson, 2007) of the total sediment load.

The data for annual SSLs and suspended-sand loads (SSDLs) used in the analyses were obtained from preexisting USGS and USACE published or unpublished daily or annual loads, or were calculated specifically for this study using concentration and daily streamflow data. Sources of sediment load, sediment concentration, and streamflow data used in this study are provided by Heimann and others (2010) and Heimann and others (2011). Annual SSL and SSDL values were computed for this study using the LOADEST program and technique (Runkel and others, 2004). The S-LOADEST version of the program, written for the commercial statistical package TIBCO Spotfire S+ (TIBCO Software Inc., version 8.1), was used to compute load estimates as described by Heimann and others (2010). LOADEST incorporates explanatory variables of streamflow (a linear or quadratic relation), time (a linear or quadratic relation), and season into one of nine predefined regression models.

The analysis of trends in annual loads (and corresponding annual flow-weighted concentrations) can be problematic when the loads are estimated from a single model. In such situations, the estimated loads are not independent from one another and are likely to be less variable over time than the actual loads. As a result, the probability of a Type I error (false positive) in the subsequent test for trend is inflated (the probability of detecting a trend is inflated). In this study, a moving-window approach was used in the estimation of the annual LOADEST sediment loads to address these two issues. The load model for a given year was developed using 3,5 , or 7 years (determined by data availability) of suspended-sediment or suspended-sand concentration data centered about the computation year. For example, assuming a 3-year window, the model for the load estimate for 1975 used calibration data from 1974-1976; the model for the 1976 estimate used calibration data from 1975-1977; the model for the 1977 estimate used calibration data from 1976-1978; the model for the 1978 estimate used calibration data from 1977-1979, and so forth. Only those load estimates derived from unique calibration data sets were used in the trend analyses. In this example, estimates from every third year (1975, 1978, and so forth) were included. The calibration data set used in the computation of each of the annual loads included in statistical analyses was unique; no calibration data point was used in more than one window. As a result, the loads used in the trend analysis all were independent from one another. The use of unique models for each window also allowed the model coefficients to change over time, thereby incorporating variability in the relation between load and streamflow and season over time. As a result, the loads used in the trend analysis also were more variable over time than if they had been derived from a single model with fixed coefficients. The moving-window approach likely only partially addressed the variability issue; because the loads are modeled estimates, some of the variability present in actual loads may still be missing. Because data used in the computation of annual loads by the tabular day-by-day method (U.S. Army Corp of Engineers, 1976; Porterfield, 1977) and turbidity surrogate methods (Rasmussen and others, 2009) were from the year of computation, all annual loads computed using these methods were included in the statistical analyses.

To determine if trends in sediment loads could be affected by combining results from multiple sediment-load computation methods, annual loads within overlapping periods of published and calculated loads were compared. Computed (LOADEST) and published (day-by-day method) SSLs from seven stations with a total of 223 years of overlapping record were compared by station. When the same SSC data used in computing the published loads were used in the LOADEST computations, there were no statistically significant differences in the annual SSLs. The lack of significant difference was based on the Wilcoxon signed rank test (Helsel and Hirsch, 2002) using a significance level of 0.05 . The probability 
Table 2. U.S. Geological Survey (USGS) streamgaging stations in the Mississippi River Basin used in study.

$\left[\mathrm{km}^{2}\right.$, square kilometer $]$

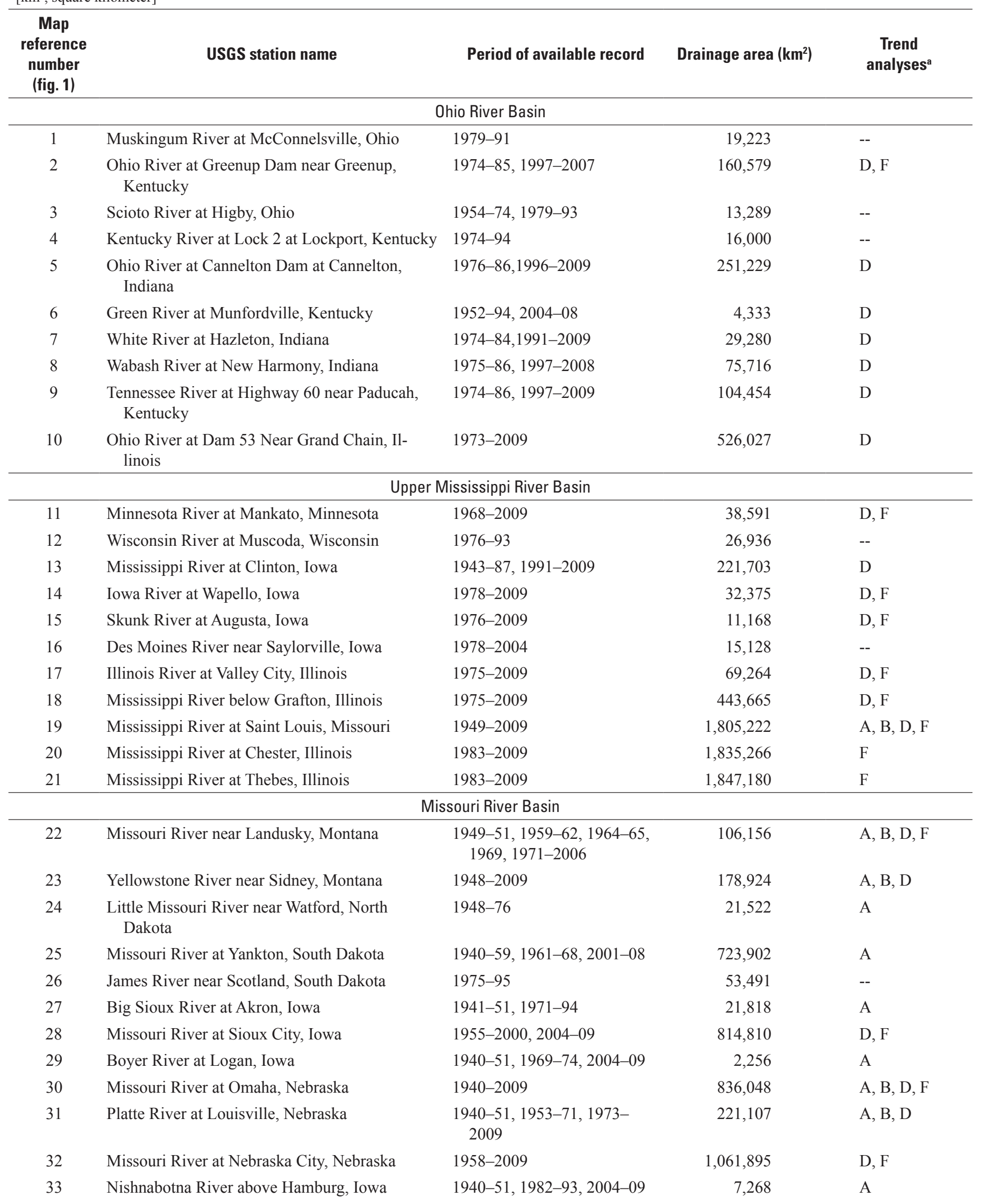


Table 2. U.S. Geological Survey (USGS) streamgaging stations in the Mississippi River Basin used in study.-Continued

$\left[\mathrm{km}^{2}\right.$, square kilometer $]$

\begin{tabular}{|c|c|c|c|c|}
\hline $\begin{array}{c}\text { Map } \\
\text { reference } \\
\text { number } \\
\text { (fig. 1) }\end{array}$ & USGS station name & Period of available record & Drainage area $\left(\mathbf{k m}^{2}\right)$ & $\begin{array}{c}\text { Trend } \\
\text { analyses }^{\mathrm{a}}\end{array}$ \\
\hline \multicolumn{5}{|c|}{ Missouri River Basin-Continued } \\
\hline 34 & Nodaway River at Clarinda, Iowa & $1970-74,1976-92$ & 1,974 & -- \\
\hline 35 & Missouri River at Saint Joseph, Missouri & 1949-2009 & $1,104,630$ & $\mathrm{~A}, \mathrm{~B}, \mathrm{C}, \mathrm{D}, \mathrm{E}, \mathrm{F}$ \\
\hline 37 & Kansas River at DeSoto, Kansas & $1949-74,1976-91,2000-05$ & 154,767 & A \\
\hline 38 & Missouri River at Kansas City, Missouri & $1949-81,1988-2009$ & $1,253,813$ & $\mathrm{~A}, \mathrm{~B}, \mathrm{C}, \mathrm{D}, \mathrm{E}$ \\
\hline 39 & Grand River near Sumner, Missouri & 1974-93 & 17,819 & -- \\
\hline 40 & Chariton River near Prairie Hill, Missouri & $1978-86$ & 4,843 & -- \\
\hline \multicolumn{5}{|c|}{ Arkansas River Basin } \\
\hline 44 & Arkansas River at Tulsa, Oklahoma & $1950-95$ & 193,252 & $\mathrm{~B}$ \\
\hline 45 & $\begin{array}{l}\text { Arkansas River at David D. Terry Lock and Dam } \\
\text { below Little Rock, Arkansas }\end{array}$ & $1941-2009$ & 410,329 & $\mathrm{~B}, \mathrm{D}$ \\
\hline \multicolumn{5}{|c|}{ Lower Mississippi River Basin } \\
\hline 46 & $\begin{array}{l}\text { Mississippi River at Tarbert Landing, Missis- } \\
\text { sippi }\end{array}$ & $1950-2009$ & $2,913,478$ & $\mathrm{~A}, \mathrm{~B}, \mathrm{D}, \mathrm{F}$ \\
\hline 47 & $\begin{array}{l}\text { Old River Outflow Channel near Knox Landing, } \\
\text { Louisiana }\end{array}$ & 1966-2009 & Indeterminate & $\mathrm{D}, \mathrm{F}$ \\
\hline 48 & Atchafalaya River at Simmesport, Louisiana & $1952-2009$ & $226,805^{\mathrm{b}}$ & $\mathrm{B}, \mathrm{D}, \mathrm{F}$ \\
\hline
\end{tabular}

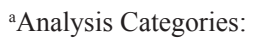

A - Step trends in suspended sediment and suspended sand, pre-1953 and post-1967 periods

B - Trends in suspended sediment, 1950-2009

C - Trends in suspended sand, 1950-2004

D - Trends in suspended sediment, 1976-2009

E - Trends in suspended sand, 1975-2004

F - Trends in suspended sediment 1998-2009

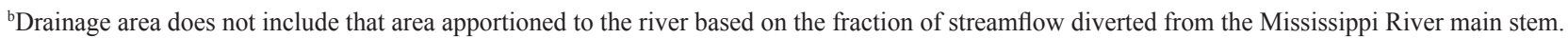

values of the comparison tests $(0.07-1.0)$ exceeded the significance level of 0.05 indicating that the chances the differences between the distributions were not true were greater than the specified significance level. Therefore, the LOADEST moving window approach allowed for the use of independent, annual SSL estimates in determining trends in loads and produced annual loads that were statistically comparable to previously published values.

\section{Trend Analyses}

Temporal changes in streamflow and suspended-sediment loads and concentrations were assessed using statistical analyses of step trends (test to determine if median differences between data values for two time periods are significantly different than zero), statistical analyses of monotonic trends (test to determine if the average rate of change of the data for a specified time period is significantly different than zero), and qualitative presentations of temporal relations. Such analyses provide an indication of the magnitude and direction of changes in sediment transport characteristics and streamflows at specific stations that, when taken collectively, can explain net changes in transport on a basin scale.

\section{Step Trends}

Step-trend analyses were conducted on the annual SSL, flow-weighted (FW) SSC (the ratio of the annual sediment load and annual streamflow, expressed in milligrams per liter), and streamflow data to identify and evaluate the effects of the 
construction of main-stem Missouri River impoundments and other land-use and channel modifications in the Missouri River Basin, on suspended-sediment transport characteristics at selected stations in the Missouri and lower Mississippi Rivers. A step-trend approach was selected because the impoundment completion dates were well defined (table 1) and spanned a relatively short time period. Similar step-trend analyses were not made with data for the remaining major subbasins of the Mississippi River Basin because the sediment-altering event was not well defined, available pre-event sediment data were limited, or the sediment-altering event predated the available sediment record entirely. The step trends in SSLs, FW SSCs, and streamflows were determined for the periods corresponding to pre- and post-Missouri River main-stem impoundment construction. The statistical comparison of the sediment and streamflow data for the pre- and post-impoundment periods was conducted using a Wilcoxon Rank Sum test at a significance level of 0.05 . Whereas the Missouri River impoundments would directly affect only the Missouri and downstream Mississippi River main-stem stations, Missouri River tributary stations with available record also were included in the step-trend analyses to assess the occurrence and magnitude of secondary factors (for example, tributary impoundments or implementation of conservation practices) on sediment transport during the analysis periods.

\section{Monotonic Trends and Qualitative Temporal Variations in Suspended-Sediment Loads, Concentrations, and Streamflow}

Monotonic trends (increases or decreases without reversals) in SSL, FW SSC, and streamflow data were determined for selected stations and for three trend periods - 1950-2009, 1976-2009, and 1998-2009_ using the Mann-Kendall test (Mann, 1945; Kendall, 1975) at a significance level of 0.05 and Sen slope estimates (Sen, 1968) within the TIBCO Spotfire S+ (TIBCO Software Inc., version 8.1) statistical package. The computed Kendall rank correlation coefficients (Kendall's tau) range from 1 to -1 with a value of 1 indicating the ranking of the two variables are the same, a value of -1 indicating the rankings are the reverse of each other, and a value of 0 indicating the absence of association. Only stations with a minimum of seven annual load, concentration, and streamflow values spanning the trend period were used in the analyses.

Monotonic trends in SSDL, FW SSDC (the ratio of the annual sand load and annual streamflow, expressed in milligrams per liter), and SSDL percentage of SSL data were computed for three stations with available continuous sandfraction record including the Missouri River at Saint Joseph, at Kansas City, and at Hermann, Missouri. Trends were computed for two periods - 1950-2004 and 1976-2004 - using the Mann-Kendall test and Sen slope estimates.

Qualitative temporal variations in annual SSL and SSDL and flow-adjusted (FA) SSC (the positive and negative residuals of SSC values, expressed in milligrams per liter, resulting from a linear regression model of observed streamflow and SSC pairs) and FA SSDC (the positive and negative residuals of SSDC, expressed in milligrams per liter, resulting from a linear regression model of observed streamflow and SSDC pairs) data also were assessed using locally estimated scatterplot smoothing (LOESS) curves (Cleveland and Devlin, 1988). Qualitative temporal relations in FA concentrations were determined to evaluate the changes in SSC (for the 1950-2009, 1976-2009, and 1998-2009 periods) and SSDCs (for the 1950-2004 and 1976-2004 periods) resulting from effects other than changes in flow. These effects were determined by calculating the residuals of streamflow-sediment concentration regression models developed using the observed streamflow and concentration data for the entire trend-analysis period at a station. A LOESS curve then was fit to the positive and negative residuals of the models to qualitatively assess changes in the FA concentrations with time.

\section{Suspended-Sediment Trends In The Mississippi River Basin}

The relative sediment contributions from and within each major Mississippi River subbasin including the Missouri, Ohio, upper Mississippi and lower Mississippi River Basins were computed. The temporal trends and qualitative temporal relations in sediment characteristics and streamflow were then assessed at multiple selected stations and for multiple time periods.

\section{Relative Sediment Contributions from Mississippi River Subbasins}

During the period 1976 through 2009, of the four primary contributing subbasins to the lower Mississippi River, the Missouri River provided the greatest median suspended-sediment load (56.9 Mt/yr (million metric tons per year)) followed by the Ohio (32.5 Mt/yr), upper Mississippi (22.5 Mt/yr), and Arkansas Rivers (2.4 Mt/yr). The Missouri River provided the largest annual SSLs during 26 of the 34 years analyzed and the Ohio River transported the largest annual SSLs during the remaining 8 years (fig. 2). The large sediment contributions of the Missouri River to the lower Mississippi River have been well documented (Keown and others, 1981; Meade and Parker, 1985; Meade and others, 1990; Meade and Moody, 2010) and overall, sediment transport in the lower Mississippi River is most closely correlative with the contributions of suspended sediment from the Missouri River Basin.

Annual SSLs were computed for gaged tributary streams within the Missouri, Ohio, and upper Mississippi Basins to further determine major sediment-contributing sources within the subbasins. SSLs were computed for 12 primary Missouri River tributary stations for the period 1975-91. The Grand River near Sumner, Missouri had the largest median annual 
SSL (10.8 Mt) and the next largest sediment contributors were the Platte River at Louisville, Nebraska (9.6 Mt), and Yellowstone River at Sidney, Montana ( (9.0 Mt) (table 3).

The median load from these tributary rivers represented 14-16 percent of the 1975-91 median load of the Missouri River at Hermann, Missouri. Such comparisons are not meant to imply that all sediment transported from the tributary stations will pass the outlet station in a continuous manner because the sediment may be temporarily deposited or "trapped", in this case, in intervening navigation dams, and sediment likely is transported episodically between the stations.

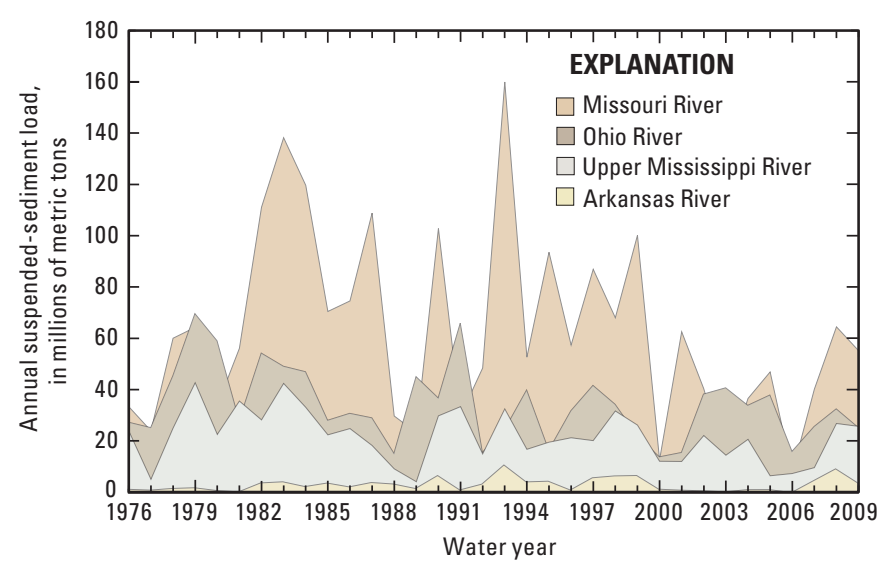

Figure 2. Annual suspended-sediment loads of the Missouri, Ohio, upper Mississippi, and Arkansas Rivers, 1976-2009.

Data from six gaged Ohio River tributary stations were analyzed for sediment load contributions during the record period of 1979-86. The Wabash River, with a median annual load of $11.5 \mathrm{Mt}$, provided the largest sediment contribution to the Ohio River (table 3). The Wabash River accounted for about 23 percent of the sediment load of the Ohio River at Grand Chain, Illinois, whereas the next largest contributors (Tennessee and Muskingum Rivers) each accounted for about 2 percent of the total Ohio River sediment load.

Analyses of records of sediment contributions from five, gaged, upper Mississippi River tributary stations for the 1978-93 period indicated that the Illinois River at Valley City, Illinois was the largest sediment contributor (table 3 ). The median annual sediment load of $5.9 \mathrm{Mt}$ was about 22 percent of the upper Mississippi River Basin suspended-sediment load during the period. The Iowa River at Wapello, Iowa (2.9 Mt), and Skunk River at Augusta, Iowa (2.6 Mt), each accounted for more than 8 percent of the median annual SSL at the upper Mississippi River outlet station at Grafton, Illinois.

All four major subbasins contributing sediment to the lower Mississippi River have main-stem and tributary structures that retard sediment transport and increase the relative contributions of sediment from tributaries downstream from primary channel control structures. Of the 22 gaged major tributary basins included in the sediment contribution analyses,
15 were impounded by major structures on their main stems (table 3).

The largest contributor of suspended sand to the lower Missouri River between 1981 and 1991 was estimated to be the main-stem reach from the Gavins Point Dam, South Dakota, to Sioux City, Iowa, followed by contributions from the Platte River in Nebraska (table 4). Much of the transported suspended sand in the Gavins Point to Sioux City reach likely is from scour of the main channel as the SSDL increased from near zero in Gavins Point Dam outflows (Paul Boyd, U.S. Army Corp of Engineers, personal commun., 2011) at Yankton, South Dakota, to $6.36 \mathrm{Mt} / \mathrm{yr}$ at Sioux City, Iowa (table 4), about $122 \mathrm{~km}$ downstream, with little or no input from the small interim tributaries. SSDL estimates for the Platte River near Louisville, Nebraska, station were about $4.6 \mathrm{Mt} / \mathrm{yr}$. The $6.36 \mathrm{Mt} / \mathrm{yr}$ estimated SSDL from channel scour, along with the 4.6 Mt/yr estimate contribution from the Platte River, alone account for about 50 percent of the $19.7 \mathrm{Mt} / \mathrm{yr}$ median SSDL at Hermann, Missouri. If additional potential diversions that substantially reduce flows take place in the Platte River (Sidle and Faanes, 1997) there likely will be a substantial reduction in SSDLs from this primary tributary. About 3.0 Mt/yr (on average) of sand were contributed to the Missouri River from tributaries between Kansas City and Hermann, Missouri, with the Grand River near Sumner, Missouri, and Chariton River near Prairie Hill, Missouri, stations having estimated median SSDLs in excess of $1.2 \mathrm{Mt} / \mathrm{yr}$.

The longitudinal gradient in Missouri River sand transport is evident in the results as the 1981-91 median sand load as a percentage of total load decreased from 62 percent at the Missouri River at Sioux City, Iowa, station to 25 percent at the Missouri River at Hermann, Missouri (table 4). Reported sand fractions of total loads during 1981-91 at the Mississippi River at Tarbert Landing, Mississippi, were 15 percent (U.S. Army Corp of Engineers, New Orleans District, unpub. data, 1950-2006).

\section{Step Trends}

Results of step-trend analyses to examine changes in annual SSLs, SSDLs, FW SSCs, FW SSDCs, and streamflows between the pre-and post-Missouri River main-stem impoundment periods indicated decreases in SSLs and SSCs at most stations. Significant (Wilcoxon Rank Sum test, $\mathrm{p}$ $<0.001-0.042$ ) decreases in SSLs were determined at all stations except one Missouri River main-stem station upstream from the impoundments and one Missouri River tributary station (table 5). Differences in pre- and post-impoundment SSLs could not be explained simply by corresponding differences in flows as changes in flows between the two periods generally were not statistically different (table 5).

The greatest difference in median SSLs between the two periods (-99.8 percent) was recorded at the Missouri River at Yankton, South Dakota, about $8 \mathrm{~km}$ downstream from Gavins Point Dam. The difference of about $126 \mathrm{Mt}$ between 
Table 3. Summary of contributions of suspended-sediment loads from gaged tributaries to major subbasins of the lower Mississippi River Basin.

[SSL, suspended-sediment load; SSC, suspended-sediment concentration; $\mathrm{mg} / \mathrm{L}$, milligrams per liter; $\mathrm{km}^{2}$, square kilometer; $\mathrm{m}^{3} / \mathrm{s}$, cubic meters per second]

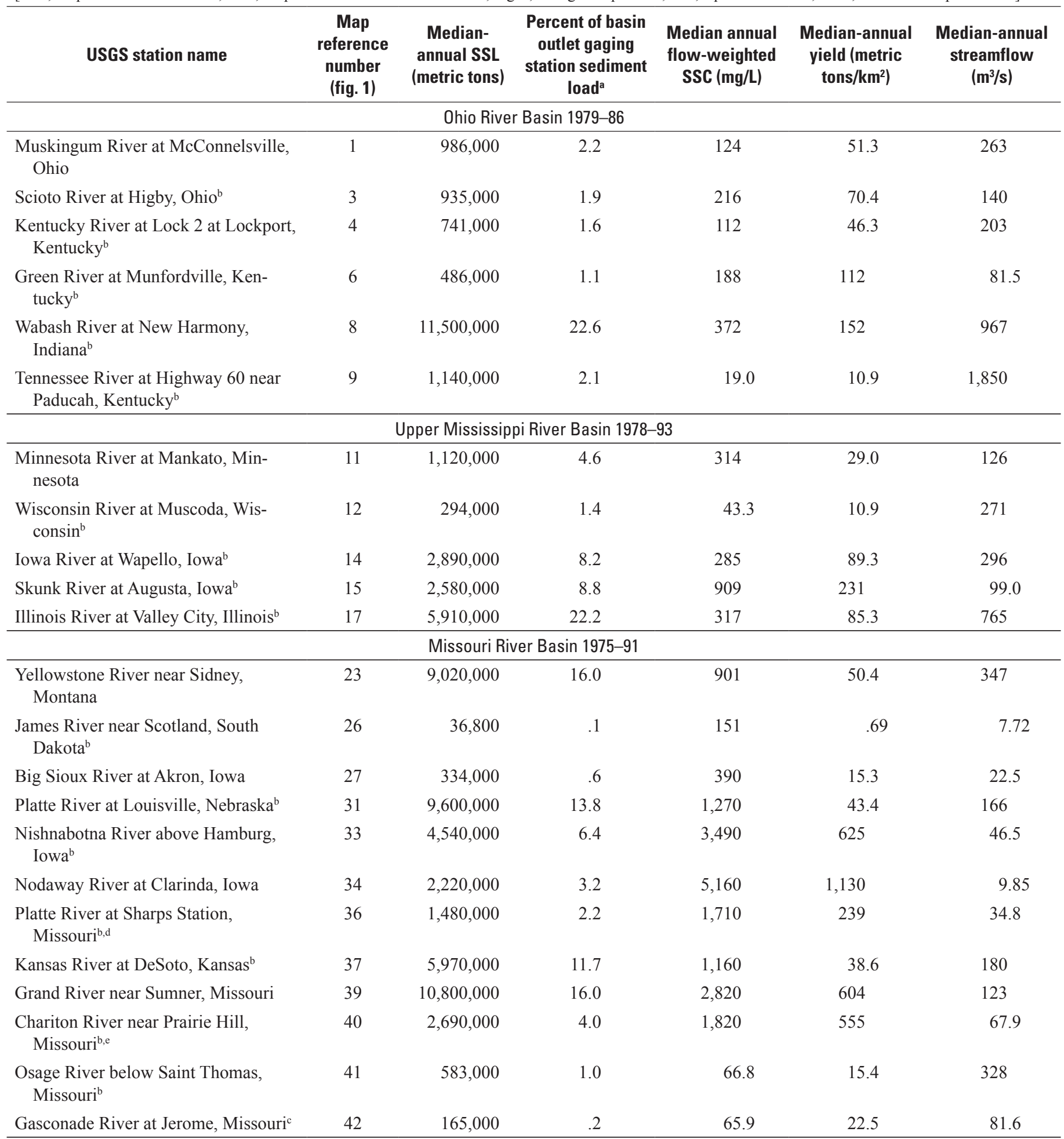

${ }^{a}$ Outlet gage for the Ohio River is the Ohio River at Grand Chain, Illinois; upper Mississippi River is the Mississippi River at Grafton, Illinois; and the Missouri River is the Missouri River at Hermann, Missouri.

${ }^{\mathrm{b}}$ Main-stem upstream from gaging station is controlled by at least one permanent impoundment.

${ }^{\mathrm{c}} 1982-91$ median.

d1980-91 median.

${ }^{\mathrm{e}} 1989-91$ median. 
Table 4. Median annual suspended-sand loads at selected Missouri River Basin streamgaging stations, $1981-91$.

$\underline{[--, \text { not applicable }]}$

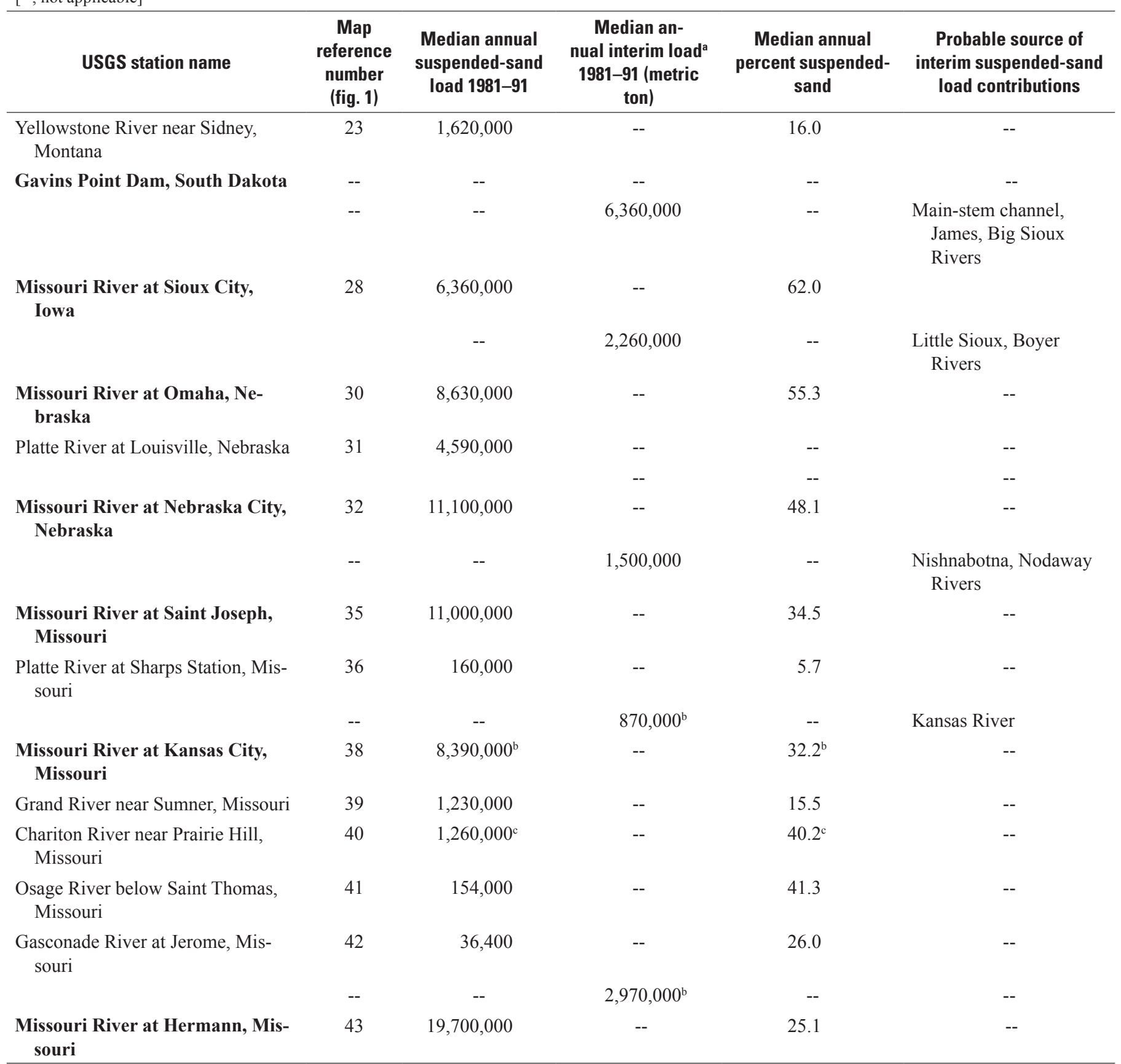

${ }^{a}$ Median difference between main-stem stations (shown in bold).

b1981, 1988-91 median.

c1981-86 median.

the pre-1953 and post-1967 periods at this station provides a median annual estimate of sediment trapped by the upstream reservoirs. This represents about 56 percent of the $224 \mathrm{Mt}$ post-impoundment median annual "deficit" at Hermann, Missouri. The remaining $98 \mathrm{Mt}$, or 44 percent, of the Hermann load reduction can be attributed to other factors including reductions in sediment from tributaries. Although the stations on the Missouri River near Landusky, Montana, and the Yellowstone River near Sydney, Montana, are upstream from the impoundments, the post-impoundment values of SSL and SSC at the stations showed reductions from pre-impoundment values of about 50 percent. The most likely cause for the reduction in sediment transport in these tributaries/reaches is trapping of sediment by impoundments as there is little $(<8$ percent) cropland agriculture in these basins (Zelt and others, 1999; U.S. Department of Agriculture, 2009). Similarly, the SSL values for the Kansas River at Desoto, Kansas, showed an 89 percent reduction in SSLs between the two periods as 
11 major reservoirs were completed in this basin between 1953 and 1967 (U.S. Army Corp of Engineers, 2009a).

Records from only five tributaries to the lower Missouri River were sufficient to be included in the step-trend analysis, but the median reduction in SSLs from these tributaries alone was about $69 \mathrm{Mt} / \mathrm{yr}$ or 70 percent of the remaining $98 \mathrm{Mt} / \mathrm{yr}$ load reduction at Hermann, Missouri. About 47 percent of the post1967 SSL reduction of the lower Mississippi River (Mississippi River at Tarbert Landing, Mississippi, and the Atchafalaya River at Simmesport, Louisiana) could be accounted for by post-impoundment reductions from the Missouri River at Hermann, Missouri.

Post-impoundment Mississippi River SSDLs were significantly lower than pre-impoundment values at the Mississippi River at Tarbert Landing, Mississippi (table 5), although the decline in sand loads (-55 percent) and FW SSDCs (-55 percent) were not as great as the decline in SSLs (-73 percent) and FW SSCs (-65 percent). Declines in postimpoundment sand loads and concentration also were less than corresponding declines in total loads and concentrations at the Missouri River at Saint Joseph, Kansas City, and Hermann.

Corresponding differences in pre- and post-impoundment distributions of FW SSCs were significant at most stations, whereas differences in the distributions of streamflow were not significant at most stations (table 5). Decreases in median values of FW SSCs ranged from 29 to more than 99 percent, with the largest decline again at the Missouri River at the Yankton, South Dakota station. Changes in annual streamflows during these periods were significant at only 4 of the 15 stations listed in table 5 .

\section{Monotonic Trends and Qualitative Temporal Relations}

Monotonic trends and qualitative temporal relations were determined for suspended-sediment and streamflow data for the last 60 years of available record (1950-2009), 34 years (1976-2009) and 12 years (1998-2009). Similarly, monotonic trends and qualitative temporal relations for suspended-sand concentrations and loads were determined for the last 55 years of available record (1950-2004) and 29 years (1976-2004).

\section{Suspended Sediment 1950-2009}

By 1950, some channel modifications or navigation structures already were in place, or in progress, in all major subbasins of the Mississippi River Basin, but most of the mainstem Missouri River impoundments and Arkansas River Basin navigation structures and reservoirs had yet to be constructed. Also, land-conservation practices were in place because of the passage of the Soil Conservation Act of 1935 (Steiner, 1987). The 1950s and 1960s were a channel-modification period in the Missouri, Arkansas, and lower Mississippi Rivers.
The results of the trend analyses of data for the period 1950 through 2009 indicate that downward trends in SSLs and FW SSCs were widespread throughout the Missouri and lower Mississippi River Basin main-stem stations. There were significant (Mann-Kendall test; $\mathrm{p}<0.001-0.032$ ) downward trends in SSLs and FW SSCs at most stations (fig. $3 A, 3 B$, table 6). Downward trends in SSLs were significant at all stations within the Missouri and lower Mississippi River subbasins but not at the representative stations within the upper Mississippi, Ohio, or Arkansas River subbasins. Cumulative reductions in sediment transport in the Missouri and lower Mississippi Rivers resulted in an overall reduction of about -1.3 percent/yr at the Mississippi River at Tarbert Landing, Mississippi, and -1.8 percent/yr at the Atchafalaya River at Simmesport, Louisiana, over the 60 -year period. Downward trends in FW SSCs were significant at all but one upper Missouri River station (fig. $3 B$, table 6). Median slopes in streamflow temporal changes generally were upward, with significant trends in streamflow detected at about one-half of the stations (fig. $3 C$, table 6 ).

Decreasing SSLs, despite concurrent increases in streamflow indicate, at most stations, that sediment declines can be explained by a decline in source material. Abrupt declines in suspended sediment in the Missouri River as a result of impoundments on the upper Missouri River have been well documented (Keown and others, 1981; Meade and others, 1990; Meade 1995; Jacobson and others, 2009; National Resource Council, 2011) as has the resulting effects of these reduced contributions at downstream Mississippi River stations (Keown and others, 1986; Kesel, 1988; Mossa, 1996). Kesel (1988) notes estimated declines in SSLs in the lower Mississippi River between 1850 and 1952 of about 25 percent; therefore, pre-dam SSLs likely represent declines from earlier transport conditions but are still greater than presettlement conditions (Knox, 1977). Even the earliest pre-impoundment record used in the trend analyses made here was collected following the closing of the Fort Peck Dam in 1937 and following early channel modifications on the Missouri, Ohio, upper Mississippi and lower Mississippi Rivers. Temporal variations in annual SSLs indicated that the Missouri River impoundments accounted for the most abrupt declines during the 1950-2009 period, and the effects of reduced contributions from the Arkansas River in the mid-1960s also are evident in SSLs at the Mississippi River at Tarbert Landing, Mississippi. The steady declines in SSLs at lower Mississippi River stations that followed the 1953 declines from the Missouri River and mid-1960s declines from the Arkansas River are not as easily explained. Other factors that have been cited as contributing to the reduction of SSLs in the Mississippi River Basin, in addition to the closing of Missouri main-stem impoundments, include the decreases in sediment contributions from the Missouri River tributaries (Meade and Moody, 2010), depletion of stored sediments in the system (Knox, 1977, 1987; Trimble, 1983; Beach, 1994; Meade and Moody, 2010), and implementation of conservation measures throughout the Mississippi River Basin (Knox, 1977; Meade and 

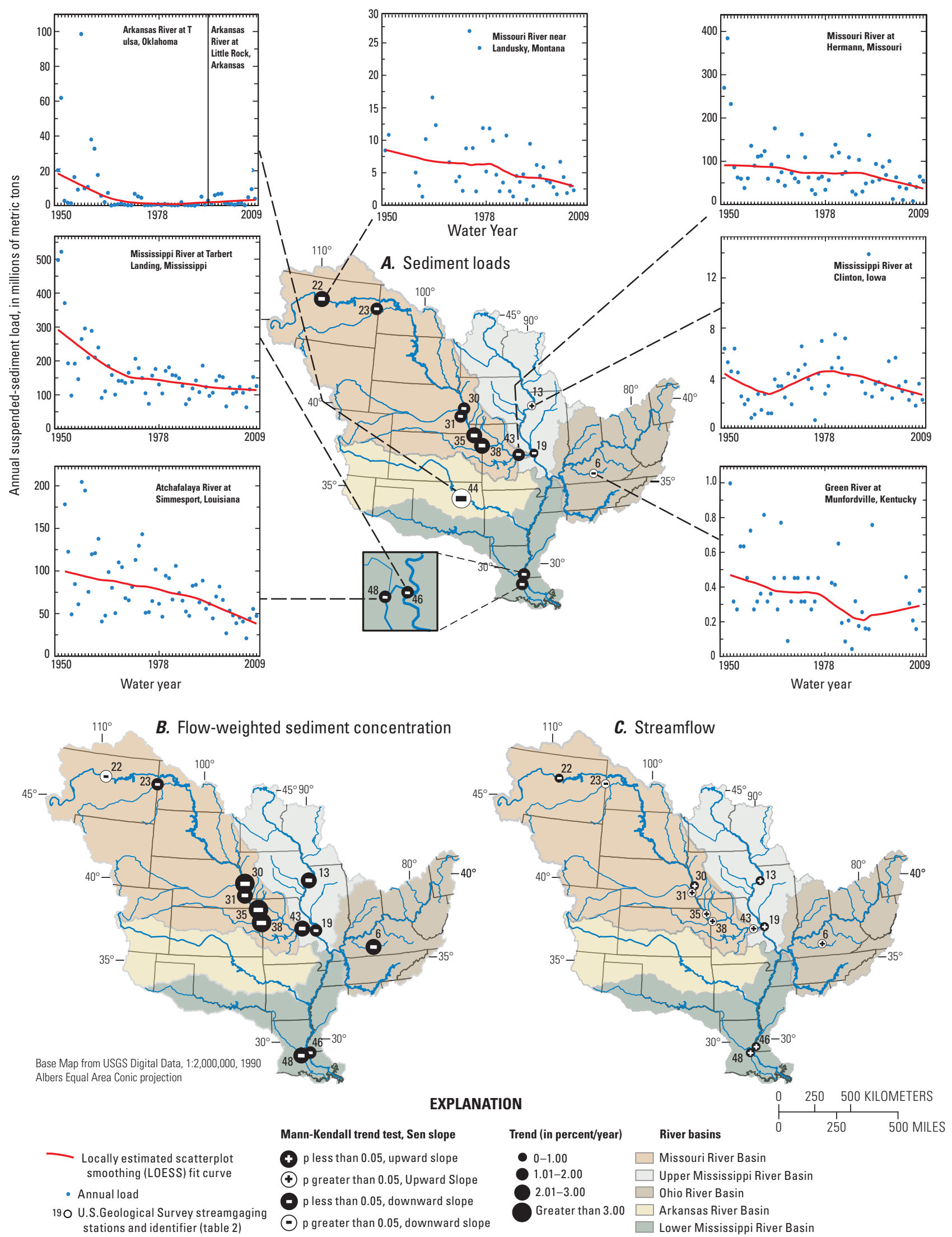

Figure 3. Summary of trends in annual suspended-sediment loads, flow-weighted concentrations, and streamflows at selected U.S. Geological Survey streamgaging stations in the Mississippi River Basin, 1950-2009. 
Table 5. Summary of step-trend analyses of suspended-sediment characteristics and streamflows for pre- (pre-1953) and postMissouri River main-stem impoundment (post-1967) periods at selected Missouri River and lower Mississippi River Basin stations.

[SSL, suspended-sediment load; SSDL, suspended-sand load; FW SSC, flow-weighted suspended-sediment concentration; FW SSDC, flow-weighted suspended-sand concentration $\mathrm{mg} / \mathrm{L}$, milligrams per liter; $\mathrm{p}$-value, statistical probability level; $\mathrm{m}^{3} / \mathrm{s}$, cubic meters per second; <, less than; --, not computed]

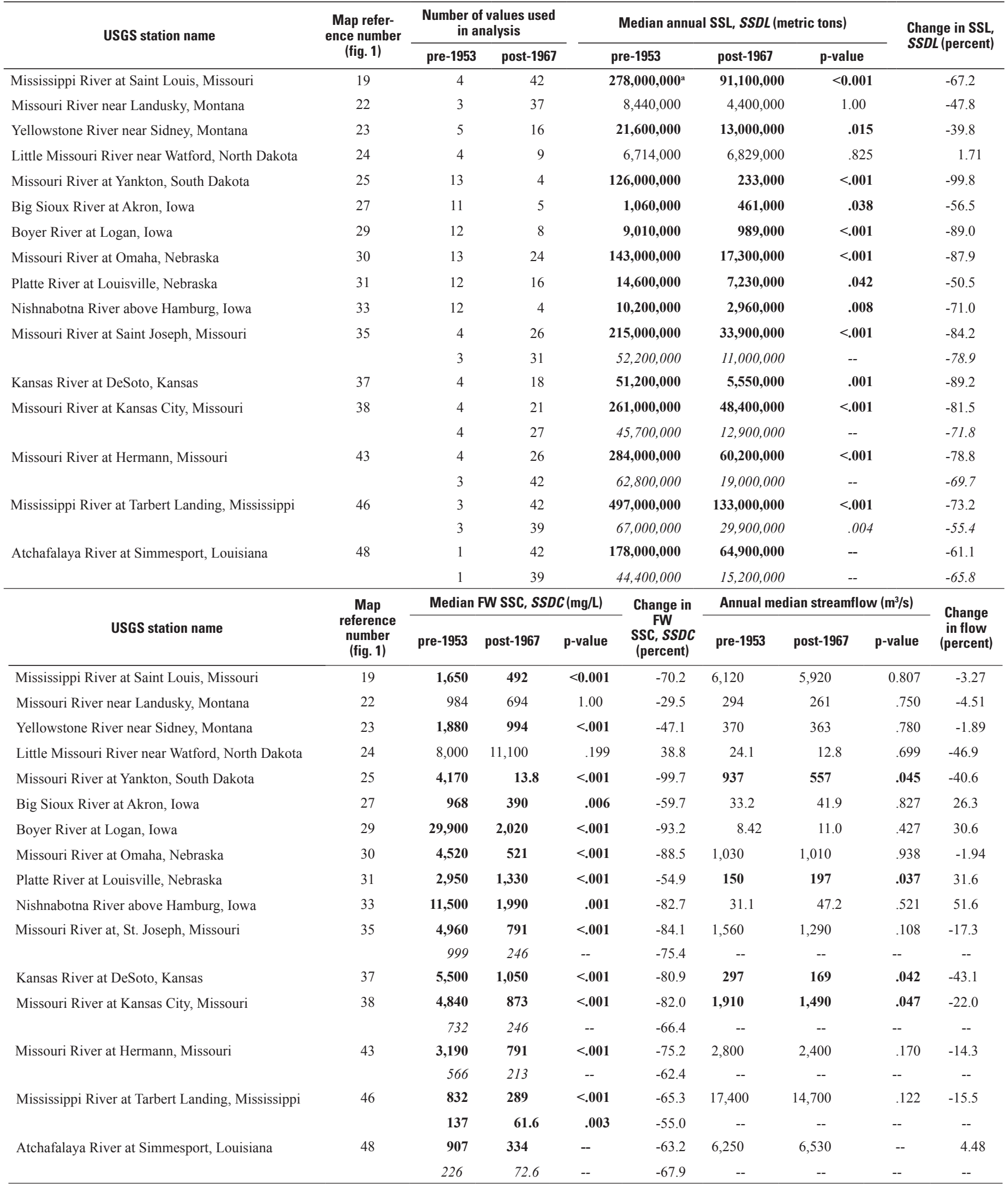

${ }^{a}$ Values in bold are statistically significant $(\mathrm{p}<0.05)$.

${ }^{\text {b} R e c o r d ~ f r o m ~ 1949-68 ~ f r o m ~ M i s s o u r i ~ R i v e r ~ n e a r ~ P o w e r ~ P l a n t ~ F e r r y, ~ M o n t a n a ~ a n d ~ f r o m ~ 1969-71 ~ f r o m ~ M i s s o u r i ~ R i v e r ~ a t ~ R o b i n s o n ~ B r i d g e ~ n e a r ~ L a n d u s k y, ~ M o n t a n a . ~}$ 
Table 6. Summary of analyses of monotonic trends in annual suspended-sediment loads, flow-weighted concentrations, and streamflows between 1950 and 2009 at selected Mississippi River Basin streamgaging stations.

[p-value, statistical probability level; mg/L, milligrams per liter; $<$, less than; yr, year; $\mathrm{m}^{3} / \mathrm{s}$, cubic meter per second]

\begin{tabular}{|c|c|c|c|c|c|c|c|}
\hline \multirow[b]{2}{*}{ USGS station name } & \multirow{2}{*}{$\begin{array}{c}\text { Map } \\
\text { reference } \\
\text { number (fig. 1) }\end{array}$} & \multirow{2}{*}{$\begin{array}{l}\text { Number of } \\
\text { values used } \\
\text { in analysis }\end{array}$} & \multicolumn{4}{|c|}{ Suspended-sediment loads } & \multirow{2}{*}{$\begin{array}{c}\text { Trend }^{\mathrm{b}} \\
\text { (in percent/ } \\
\text { yr) }\end{array}$} \\
\hline & & & $\begin{array}{l}\text { Mann-Kendall } \\
\text { tau }\end{array}$ & p-value & $\begin{array}{c}\text { Sen slope } \\
\text { (metric tons/yr) }\end{array}$ & $\begin{array}{c}\text { Median } \\
\text { (metric tons) }\end{array}$ & \\
\hline Green River at Munfordville, Kentucky & 6 & 33 & -0.227 & 0.062 & $-3,520$ & 363,000 & -0.97 \\
\hline Mississippi River at Clinton, Iowa & 13 & 40 & .076 & .499 & 12,100 & $3,360,000$ & .36 \\
\hline Mississippi River at Saint Louis, Missouri & 19 & 60 & $-.190^{\mathrm{a}}$ & .032 & $-791,000$ & $91,500,000$ & -.86 \\
\hline Missouri River near Landusky, Montana & 22 & 45 & -.271 & .009 & $-103,000$ & $4,530,000$ & -2.27 \\
\hline Yellowstone River near Sidney, Montana & 23 & 34 & -.305 & .012 & $-236,000$ & $15,200,000$ & -1.55 \\
\hline Missouri River at Omaha, Nebraska & 30 & 42 & -.524 & $<.001$ & $-422,000$ & $23,300,000$ & -1.81 \\
\hline Platte River at Louisville, Nebraska & 31 & 33 & -.311 & .012 & $-169,000$ & $8,910,000$ & -1.90 \\
\hline Missouri River at Saint Joseph, Missouri & 35 & 39 & -.457 & $<.001$ & $-829,000$ & $37,300,000$ & -2.22 \\
\hline Missouri River at Kansas City, Missouri & 38 & 44 & -.439 & $<.001$ & $-1,380,000$ & $56,500,000$ & -2.44 \\
\hline Missouri River at Hermann, Missouri & 43 & 44 & -.332 & .002 & $-1,170,000$ & $63,600,000$ & -1.84 \\
\hline Arkansas River at Tulsa, Oklahoma ${ }^{c}$ & 44 & 20 & -.232 & .163 & $-46,300$ & $1,390,000$ & -3.33 \\
\hline Mississippi River at Tarbert Landing, Mississippi & 46 & 60 & -.401 & $<.001$ & $-1,890,000$ & $142,000,000$ & -1.33 \\
\hline Atchafalaya River at Simmesport, Louisiana & 48 & 58 & -.412 & $<.001$ & $-1,170,000$ & $66,200,000$ & -1.77 \\
\hline \multirow[b]{2}{*}{ USGS station name } & \multirow{2}{*}{$\begin{array}{l}\text { Map } \\
\text { reference } \\
\text { number }\end{array}$} & \multirow{2}{*}{$\begin{array}{l}\text { Number of } \\
\text { values used } \\
\text { in analysis }\end{array}$} & \multicolumn{4}{|c|}{ Flow-weighted suspended-sediment concentrations } & \multirow{2}{*}{$\begin{array}{c}\text { Trend }^{\mathrm{b}} \\
\text { (in percent/ } \\
\text { yr) }\end{array}$} \\
\hline & & & $\begin{array}{c}\text { Mann-Kendall } \\
\text { tau }\end{array}$ & p-value & $\begin{array}{l}\text { Sen slope } \\
\text { ((mg/L)/yr) }\end{array}$ & $\begin{array}{c}\text { Median } \\
(\mathrm{mg} / \mathrm{L})\end{array}$ & \\
\hline Green River at Munfordville, Kentucky & 6 & 33 & -0.591 & $<0.001$ & -3.74 & 167 & -2.24 \\
\hline Mississippi River at Clinton, Iowa & 13 & 40 & -.699 & $<.001$ & -8.76 & 362 & -2.42 \\
\hline Mississippi River at Saint Louis, Missouri & 19 & 60 & -.513 & $<.001$ & -8.50 & 538 & -1.58 \\
\hline Missouri River near Landusky, Montana & 22 & 45 & -.164 & .115 & -6.41 & 572 & -1.12 \\
\hline Yellowstone River near Sidney, Montana & 23 & 34 & -.401 & $<.001$ & -22.5 & 1,360 & -1.65 \\
\hline Missouri River at Omaha, Nebraska & 30 & 42 & -.738 & $<.001$ & -23.2 & 765 & -3.03 \\
\hline Platte River at Louisville, Nebraska & 31 & 33 & -.468 & $<.001$ & -43.6 & 1,812 & -2.41 \\
\hline Missouri River at Saint Joseph, Missouri & 35 & 39 & -.605 & $<.001$ & -33.4 & 1,050 & -3.18 \\
\hline Missouri River at Kansas City, Missouri & 38 & 44 & -.644 & $<.001$ & -41.7 & 1,220 & -3.42 \\
\hline Missouri River at Hermann, Missouri & 43 & 44 & -.643 & $<.001$ & -27.4 & 993 & -2.76 \\
\hline Arkansas River at Tulsa, Oklahoma & 44 & 20 & -.558 & $<.001$ & -13.7 & 97.6 & -14.00 \\
\hline Mississippi River at Tarbert Landing, Mississippi & 46 & 60 & -.666 & $<.001$ & -5.74 & 313 & -1.84 \\
\hline Atchafalaya River at Simmesport, Louisiana & 48 & 58 & -.699 & $<.001$ & -8.76 & 362 & -2.42 \\
\hline \multirow[b]{2}{*}{ USGS station name } & \multirow{2}{*}{$\begin{array}{c}\text { Map } \\
\text { reference } \\
\text { number }\end{array}$} & \multirow{2}{*}{$\begin{array}{l}\text { Number of } \\
\text { values used } \\
\text { in analysis }\end{array}$} & \multicolumn{4}{|c|}{ Streamflow } & \multirow{2}{*}{$\begin{array}{c}\text { Trend }^{\mathrm{b}} \\
\text { (in percent/ } \\
\text { yr) }\end{array}$} \\
\hline & & & $\begin{array}{c}\text { Mann-Kendall } \\
\text { tau }\end{array}$ & p-value & $\begin{array}{l}\text { Sen slope } \\
\left(\left(\mathbf{m}^{3} / \mathbf{s}\right) / \mathrm{yr}\right)\end{array}$ & $\begin{array}{c}\text { Median } \\
\left(\mathbf{m}^{3} / \mathbf{s}\right)\end{array}$ & \\
\hline Green River at Munfordville, Kentucky & 6 & 33 & 0.138 & 0.260 & 0.375 & 78.2 & 0.48 \\
\hline Mississippi River at Clinton, Iowa & 13 & 40 & .280 & .011 & 9.26 & 1440 & .64 \\
\hline Mississippi River at Saint Louis, Missouri & 19 & 60 & .197 & .027 & 30.0 & 5,410 & .55 \\
\hline Missouri River near Landusky, Montana & 22 & 45 & -.337 & .001 & -2.51 & 267 & -.94 \\
\hline Yellowstone River near Sidney, Montana & 23 & 34 & -.034 & .790 & -.425 & 360 & -.12 \\
\hline Missouri River at Omaha, Nebraska & 30 & 42 & .228 & .035 & 4.36 & 866 & .50 \\
\hline Platte River at Louisville, Nebraska & 31 & 33 & .141 & .263 & .716 & 168 & .43 \\
\hline Missouri River at Saint Joseph, Missouri & 35 & 39 & .197 & .061 & 5.12 & 1,130 & .45 \\
\hline Missouri River at Kansas City, Missouri & 38 & 44 & .169 & .134 & 6.55 & 1,410 & .46 \\
\hline Missouri River at Hermann, Missouri & 43 & 44 & .200 & .057 & 14.4 & 2,220 & .65 \\
\hline Arkansas River at Tulsa, Oklahoma & 44 & 20 & -- & -- & -- & -- & -- \\
\hline Mississippi River at Tarbert Landing, Mississippi & 46 & 60 & .199 & .025 & 62.2 & 14,000 & .44 \\
\hline Atchafalaya River at Simmesport, Louisiana & 48 & 58 & .233 & .010 & 30.3 & 6,060 & .50 \\
\hline
\end{tabular}

avalues in bold are statistically significant $(\mathrm{p}<0.05)$.

${ }^{\mathrm{b}}$ Trend in percent/yr is calculated as the ratio of the Sen slope and median constituent values.

'Sediment load and record information from Arkansas River at Tulsa, Oklahoma from 1951 through 1993 and from Arkansas River at Little Rock, Arkansas from 1994 through 2006. 

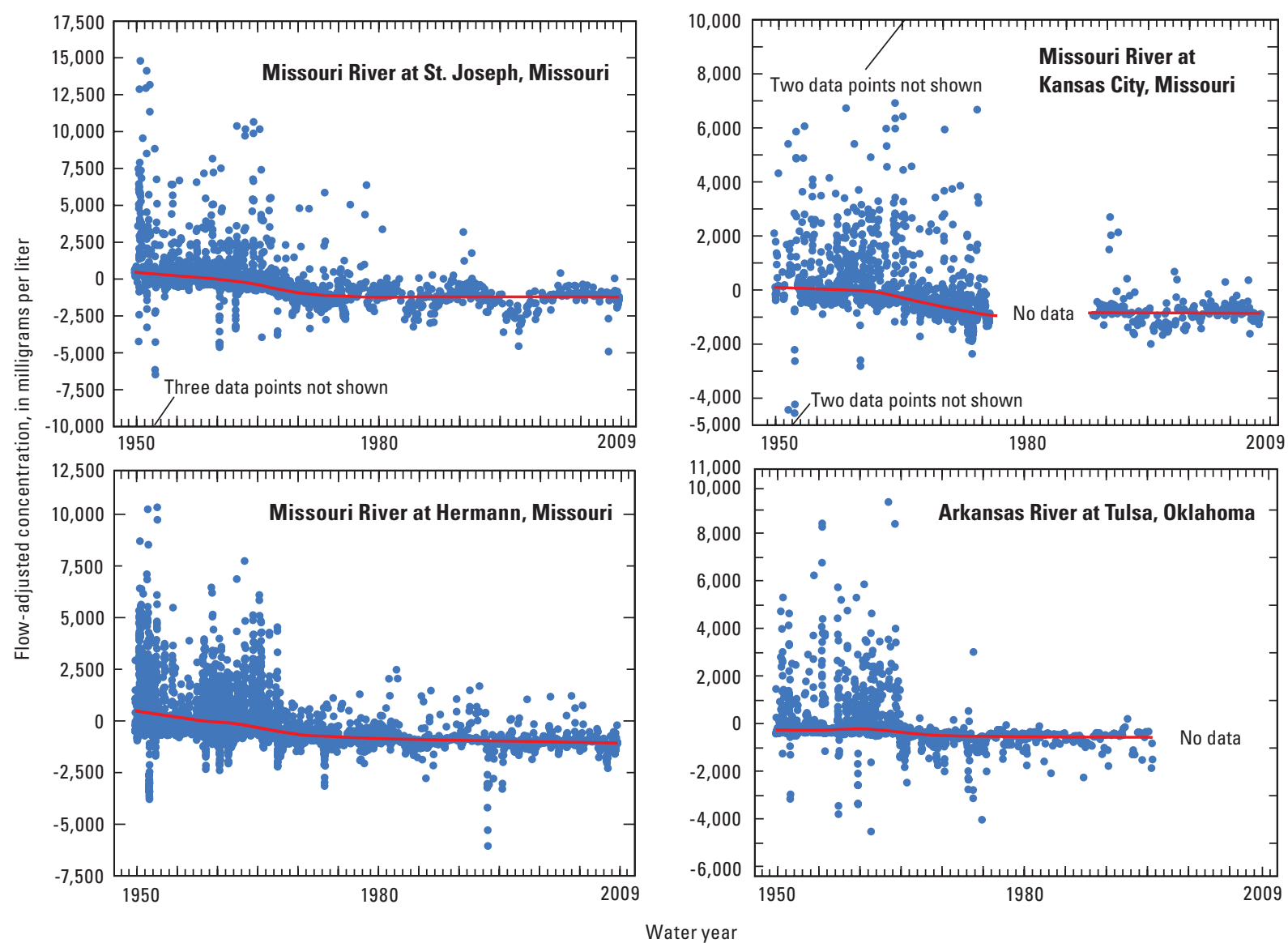

\section{EXPLANATION}

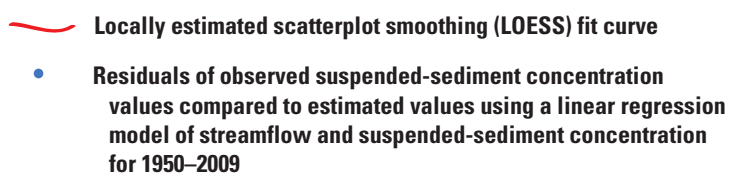

Figure 4. Summary of temporal variations in flow-adjusted concentrations for selected U.S. Geological Survey streamgaging stations in the Mississippi River Basin, 1950-2009.

Moody, 2010). Most gaged tributaries within major Mississippi River subbasins have main-stem impoundments (table 3) that could account for much of the sediment transport deficit not accounted for directly by the Missouri River main-stem impoundments.

The Arkansas River is the primary tributary sediment contributor to the lower Mississippi River Basin and there were significant decreases in SSLs in this basin during the 1950-2009 period. SSLs at the Arkansas River at Tulsa, Oklahoma, station decreased abruptly in the mid-1960s and this likely was the result of the construction of impoundments and navigation structures associated with the McClellan-Kerr navigation system. Keown and others (1986) noted substantial declines in SSLs at a downstream station, the Arkansas River at Little Rock, Arkansas, at which the 1941-62 average SSL was about $93 \mathrm{Mt} / \mathrm{yr}$ and the 1970-78 average was about 11.4 Mt/yr. This represents about an 88 percent reduction in SSLs from the Arkansas River Basin and exceeds the 79 percent reduction in SSLs in the Missouri River Basin (Missouri River at Hermann, Missouri, station; table 5) that followed channel modifications.

Decreases in SSLs in the lower Mississippi River corresponding to the declines in the Missouri and Arkansas Rivers were immediate and substantial. Pre-1953 (pre-Missouri River impoundment) SSLs in the lower Mississippi River (Mississippi River at Tarbert Landing, Mississippi, and Atchafalaya River at Simmesport, Louisiana) averaged $641 \mathrm{Mt} / \mathrm{yr}$. This average declined to $296 \mathrm{Mt} / \mathrm{yr}$ during the 1953-64 period and to $198 \mathrm{Mt} / \mathrm{yr}$ following declines in contributions from the Arkansas River Basin in the mid-1960s (fig. 3) - a total SSL reduction of about 69 percent.

FA SSCs for Missouri River and Arkansas River stations decreased during the 1950-2009 analysis period (fig. 4). Plots of FA SSCs show downward changes in the fitted LOESS curves for each Missouri River station indicating deviations from the overall streamflow-SSC relation. At 
each station there were changes in the transport relation in about 1962 and 1972 with no substantial changes thereafter. The large negative FA SSCs in 1951, 1952, 1973, 1993, and 1995 correspond with large floods in those years, but these events had no apparent long-term effects on FA SSCs. FA SSCs for the available 1950-95 period at the Arkansas River at Tulsa, Oklahoma, also show apparent sediment transport relation changes around 1963 and 1974 with stable relations thereafter (fig. 4). Whereas abrupt changes in annual SSLs were evident following the closing of Fort Randall Dam in 1952, the changes in FA SSCs at Saint Joseph, Kansas City, and Hermann, Missouri, were lagged and subtle. The decrease in FA SSCs at these stations indicate less suspended material was being transported for a given flow condition and likely corresponds to adjustments in the system from a transportlimited to a supply-limited system, as suggested by Horowitz (2010), and by Meade and Moody (2010). The magnitude of variability of FA SSCs declined during the mid-1960s, likely a result of regulated flows and limitations in sediment supply. The decrease in FA SSCs at the Arkansas River at Tulsa, Oklahoma, also is a likely indication of adjustments in this sediment conveyance system from a transport-limited towards supply-limited conditions.

\section{Suspended Sand 1950-2004}

Trends in SSDLs, SSDCs, and SSDL percentage of SSLs were determined for three Missouri River and two lower Mississippi River stations for 1950-2004. Significant downward trends in SSDLs were determined for the Missouri River at Saint Joseph and Kansas City, Missouri and for the Mississippi River at Tarbert Landing, Mississippi, and Atchafalaya River at Simmesport, Louisiana, stations (table 7). The downward change in SSDLs at Hermann, Missouri, however, was not significant $(p=0.055)$. Decreases in FW SSDCs were

Table 7. Summary of analyses of monotonic trends in annual suspended-sand loads, flow-weighted suspended-sand concentrations, and sand load as a percentage of total suspended-sediment load between 1950 and 2004 at selected Missouri River and lower Mississippi River Basin stations.

[p-value, statistical probability level; yr, year; mg/L, milligrams per liter; $\mathrm{m}^{3} / \mathrm{s}$, cubic meter per second; <, less than;]

\begin{tabular}{|c|c|c|c|c|c|c|c|}
\hline \multirow[b]{2}{*}{ USGS station name } & \multirow{2}{*}{$\begin{array}{l}\text { Map ref- } \\
\text { erence } \\
\text { number } \\
\text { (fig. 1) }\end{array}$} & \multirow{2}{*}{$\begin{array}{l}\text { Number } \\
\text { of values } \\
\text { used in } \\
\text { analysis }\end{array}$} & \multicolumn{4}{|c|}{ Suspended-sand load } & \multirow[b]{2}{*}{$\begin{array}{c}\text { Trend (in } \\
\text { percent/yr) }\end{array}$} \\
\hline & & & $\begin{array}{l}\text { Mann- } \\
\text { Kendall } \\
\text { tau }\end{array}$ & p-value & $\begin{array}{l}\text { Sen slope } \\
\text { (metric tons/ } \\
\text { yr) }\end{array}$ & $\begin{array}{l}\text { Median (met- } \\
\text { ric tons) }\end{array}$ & \\
\hline Missouri River at Saint Joseph, Missouri & 35 & 20 & $-0.537^{a}$ & 0.001 & $-323,000$ & $15,200,000$ & -2.13 \\
\hline Missouri River at Kansas City, Missouri & 38 & 19 & -.491 & .004 & $-298,000$ & $14,200,000$ & -2.10 \\
\hline Missouri River at Hermann, Missouri & 43 & 22 & -.299 & .055 & $-270,000$ & $19,400,000$ & -1.39 \\
\hline Mississippi River at Tarbert Landing, Mississippi & 46 & 55 & -.282 & .002 & $-550,000$ & $31,900,000$ & -1.72 \\
\hline Atchafalaya River at Simmesport, Louisiana & 48 & $53^{b}$ & -.232 & .014 & $-246,000$ & $16,600,000$ & -1.48 \\
\hline \multirow[b]{2}{*}{ USGS station name } & \multirow{2}{*}{$\begin{array}{l}\text { Map ref- } \\
\text { erence } \\
\text { number } \\
\text { (fig. 1) }\end{array}$} & \multirow{2}{*}{$\begin{array}{l}\text { Number } \\
\text { of values } \\
\text { used in } \\
\text { analysis }\end{array}$} & \multicolumn{4}{|c|}{ Flow-weighted suspended-sediment concentrations } & \\
\hline & & & $\begin{array}{l}\text { Mann-Kend- } \\
\text { all tau }\end{array}$ & p-value & $\begin{array}{l}\text { Sen slope } \\
((\mathrm{mg} / \mathrm{L}) / \mathrm{yr})\end{array}$ & $\begin{array}{l}\text { Median } \\
\text { (mg/L) }\end{array}$ & $\begin{array}{c}\text { Trend (in } \\
\text { percent/yr) }\end{array}$ \\
\hline Missouri River at Saint Joseph, Missouri & 35 & 20 & -0.747 & $<0.001$ & -10.8 & 340 & -3.18 \\
\hline Missouri River at Kansas City, Missouri & 38 & 19 & -.790 & $<.001$ & -8.69 & 346 & -2.51 \\
\hline Missouri River at Hermann, Missouri & 43 & 22 & -.533 & $<.001$ & -4.26 & 221 & -1.93 \\
\hline Mississippi River at Tarbert Landing, Mississippi & 46 & 55 & -.410 & $<.001$ & -1.61 & 73.7 & -2.18 \\
\hline \multirow[t]{3}{*}{ Atchafalaya River at Simmesport, Louisiana } & 48 & 53 & -.441 & $<.001$ & -2.24 & 90.7 & -2.47 \\
\hline & \multirow{2}{*}{$\begin{array}{c}\text { Map ref- } \\
\text { erence } \\
\text { number } \\
\text { (fig. 1) }\end{array}$} & \multirow{2}{*}{$\begin{array}{l}\text { Number } \\
\text { of values } \\
\text { used in } \\
\text { analysis }\end{array}$} & \multicolumn{4}{|c|}{$\begin{array}{l}\text { Suspended-sand load percentage of suspended-sedi- } \\
\text { ment load }\end{array}$} & \multirow{2}{*}{$\begin{array}{l}\text { Trend (in } \\
\text { percent/yr) }\end{array}$} \\
\hline & & & $\begin{array}{l}\text { Mann- } \\
\text { Kendall } \\
\text { tau }\end{array}$ & p-value & $\begin{array}{l}\text { Sen slope } \\
\left(\left(\mathrm{m}^{3} / \mathrm{s}\right) / \mathrm{yr}\right)\end{array}$ & $\begin{array}{c}\text { Median } \\
\left(\mathrm{m}^{3} / \mathrm{s}\right)\end{array}$ & \\
\hline Missouri River at Saint Joseph, Missouri & 35 & 20 & -0.179 & 0.284 & -0.393 & 33.3 & -1.18 \\
\hline Missouri River at Kansas City, Missouri & 38 & 19 & -.076 & .675 & -.125 & 27.1 & -.46 \\
\hline Missouri River at Hermann, Missouri & 43 & 22 & -.013 & .955 & -.008 & 27.6 & -.03 \\
\hline Mississippi River at Tarbert Landing, Mississippi & 46 & 55 & .017 & .861 & 0 & 20.0 & 0 \\
\hline Atchafalaya River at Simmesport, Louisiana & 48 & 53 & -.003 & .982 & 0 & 23.0 & 0 \\
\hline
\end{tabular}

${ }^{a}$ Values in bold are statistically significant $(\mathrm{p}<0.05)$.

${ }^{\mathrm{b}}$ Available sediment record is from 1952-2004. 
1950-2004

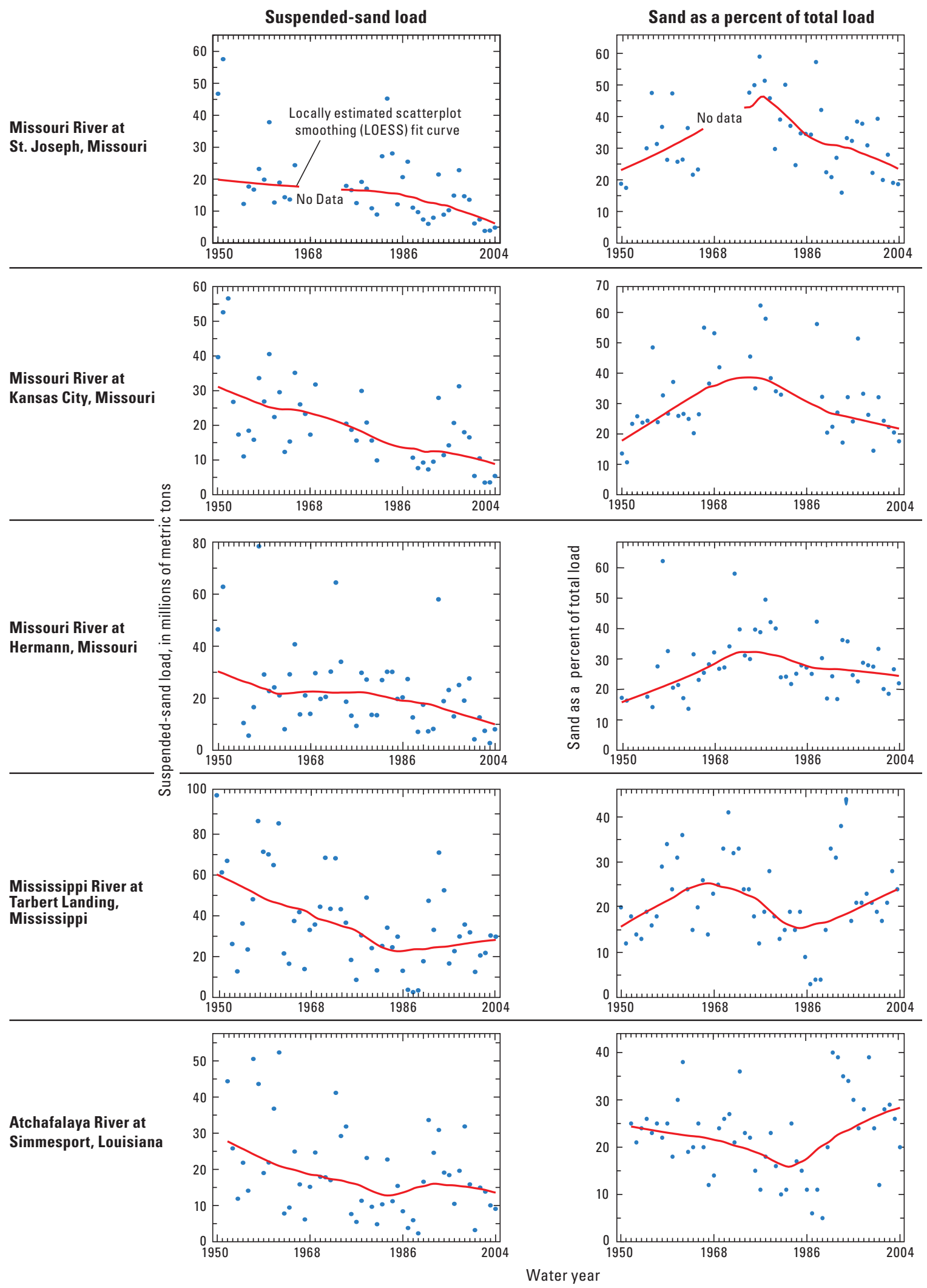

Figure 5. Summary of temporal variations in annual suspended-sand loads and annual sand as a percentage of total suspended-sediment loads, 1950-2004. 
significant at all five stations, but there were no significant monotonic trends in the sand percentage of total sediment loads at any of the five stations for the 1950-2004 period (table 7). Qualitative temporal relations in SSDLs and SSDCs indicate the declines in SSDLs were abrupt following the 1952 dam closure, but SSDL declines (fig. 5) were more gradual than declines in SSLs

(fig. 3). The corresponding temporal changes in SSDL percentage of SSLs showed increases in the portion of total loads comprised of sand between 1950 and about 1978 at all three Missouri River stations, followed by a decline in the portion of total loads comprised of sand from 1978 through 2004

(fig. 5). Similar temporal changes were not evident at the Tarbert Landing, Mississippi, or Simmesport, Louisiana, stations.

In addition to being the largest contributor of total suspended sediment to the Mississippi River, the Missouri River also is likely the largest contributor of suspended sand to the Mississippi River. The stations at Saint Joseph and Kansas City, Missouri, receive the majority of sand from the upstream main-stem channel of the Missouri and from the Platte River in Nebraska. The lack of a discernable trend in SSDLs at Hermann, Missouri, could be a consequence of the longitudinal distance from this primary source and the moderating effects in sediment transport over a great distance. Another possible moderating effect could be the substantial contributions of sand from major, and relatively unaltered, tributaries between Kansas City and Hermann (Grand and Chariton Rivers, Missouri).

An increase in SSDL percentage of SSLs from 1950 through about 1980 at the three Missouri River stations coincided with a period of declining SSLs and SSDLs (fig. 3, fig. 5) and indicated the silt and clay fractions of total load declined more than the sand fraction during this period. Further evidence of the larger declines in silt and clay fraction is indicated in the larger declines in SSLs and SSCs than SSDLs and SSDCs at several Missouri and Mississippi River stations (table 5), in the post-impoundment period. A larger decline in silt and clay fractions of sediment transport in the system could possibly reflect the effects of conservation practices in the basin that would target topsoil containing more silt and clay than sand. The reversal of this trend from 1980-2004 could be explained by the increased downward change in sand transport at these stations that began about 1980 (fig. 5), but the direct cause is unclear. The source of the change in the trend originates upstream from the Saint Joseph station and does not seem to be the result of a change in the streamflowSSDC transport relation. The larger relative decline in SSDLs may simply be the result of a low-flow period in the sand-supply reach, downstream from Gavins Point Dam, as the Sioux City station showed significant downward trends in streamflow during the 1976-2009 period (table 8).

FA SSDCs at the Missouri River at Saint Joseph, Kansas City, and Hermann, Missouri for the 1950-2004 period showed subtle but apparent slope changes in LOESS fitted curves around 1956-58 and again around 1963-70 depending on the station (fig. 6). These slope changes, therefore, preceded the changes in FA SSCs for the 1950-2009 period at these stations by about 5 years. Unlike FA SSCs, however, which showed downward slope breaks between 1950 and 1975, there was at least one period of increases in FA SSDCs between 1950 and 1970 at each of the three stations. The specific causes of the transport relation transitions are difficult to determine with available information and likely include lagged channel adaptations to the main-stem impoundments.

\section{Suspended Sediment 1976-2009}

By 1976, most of the channel modifications in the major Mississippi River subbasins had been completed, although work continued on the Missouri River through the 1980s, the McClellan-Kerr navigation system on the Arkansas River through the early 2000s, and the Red River through the early 2000s. There were downward changes in SSLs at 19 of 27 Mississippi River Basin stations and statistically significant downward monotonic trends at 9 of 27 stations during the 1976 through 2009 analysis period, including stations in all major subbasins except the Arkansas River Basin (fig. 7, table 8). Eight stations, at least one within each major subbasin, showed upward changes in SSLs although none were significant $(\mathrm{p}=0.102-0.940)$. Downward changes in FW SSCs were significant at 13 stations including stations in each of the major subbasins except the Arkansas River Basin (fig. 7, table 8). Two stations, the Missouri River near Landusky, Montana and Sioux City, Iowa, showed significant downward trends in streamflow during the 34-year analysis period (fig. 7, table 8).

During 1976-2009, most stations had stready declines in sediment loads including stations within the upper Mississippi, Missouri, Ohio, and lower Mississippi River subbasins (fig. 7). Exceptions included the Wabash River at New Harmony, Indiana, which showed variable SSLs ending with an increase, and the Iowa River at Wapello, Iowa, which also ended the period with increasing SSLs.

Although not expressed in the fitted 1950-2009 FA SSC LOESS curves for the stations on the Missouri River at Saint Joseph and Kansas City, Missouri (fig. 4), subtle downward changes appear in the fitted 1976-2009 FA SSC curves for these stations, indicating a change in the streamflow-SSC relation coinciding with the 1993 and 1995 floods (fig. 8). There was a subsequent increase in the FA SSCs beginning in about 1997 and continuing through 2003, indicating a system recovery from the 1993 and 1995 floods. There were large negative FA SSCs at the Missouri River at Hermann, Missouri, in 1993 and 1995, but these declines were not expressed in the fitted LOESS curve.

\section{Suspended Sand 1976-2004}

Trends in SSDL, FW SSDCs, and SSDL percentage of SSLs during the 1976-2004 post-impoundment period were analyzed at seven stations including four Missouri River Basin and three lower Mississippi River stations for the 1976-2004 
1950-2004
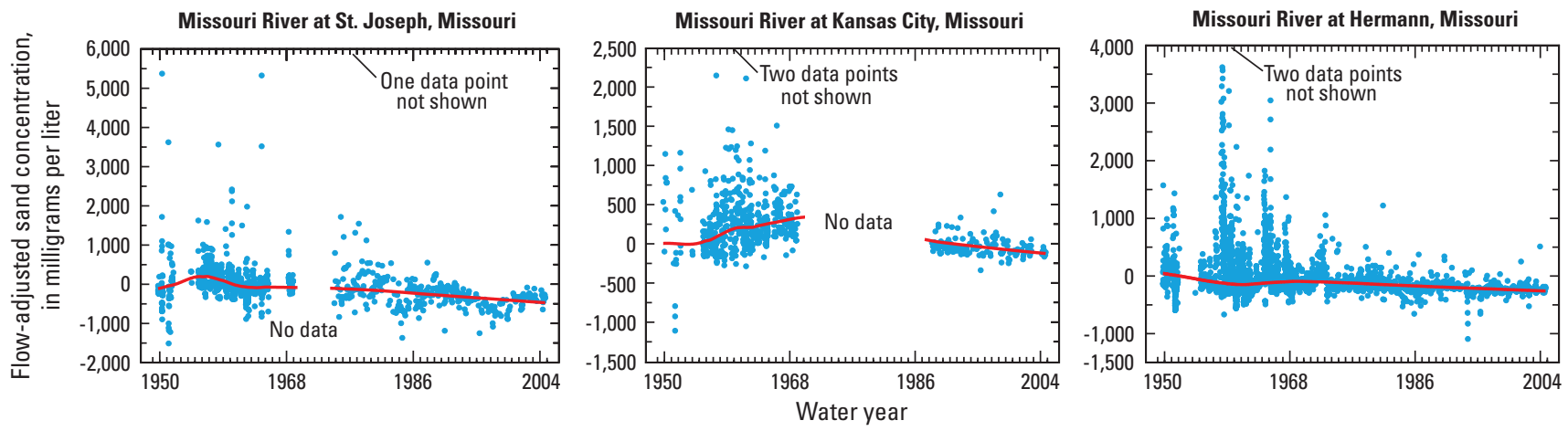

1976-2004
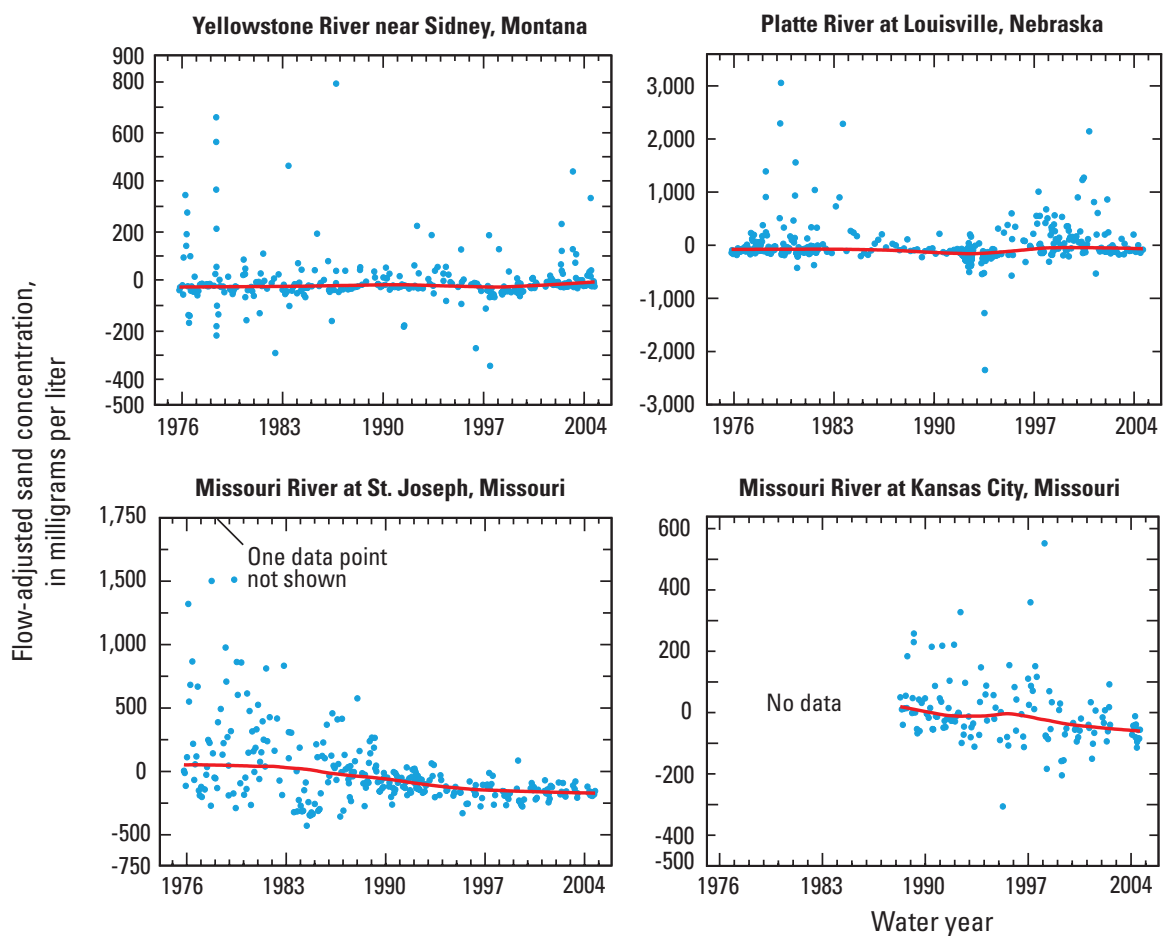

EXPLANATION

- Locally estimated scatterplot smoothing (LOESS) fit curve

Residuals of observed suspended-sediment concentration values compared to estimated values using a linear regression model of streamflow and suspended-sediment concentration for 1950-2009

Figure 6. Summary of temporal variations in flow-adjusted sand concentrations, 1950-2004 and 1976-2004.

post-impoundment period (table 9). Of the five stations with downward changes in SSDLs during this time period, two (Missouri River at Saint Joseph and Kansas City, Missouri) had significant downward trends. The remaining two stations (Mississippi River at Tarbert Landing, Mississippi, and Atchafalaya River at Simmesport, Louisiana) had upward, but not statistically significant, changes in SSDLs and SSDCs (table 9). Downward monotonic trends in FW SSDCs and the SSDL percentage of SSLs were significant at all three Missouri River main-stem stations (table 9) but not at any other stations.

Sand from the Missouri River main-stem reach between Gavins Point Dam and Sioux City, Iowa, likely was the primary contributor to SSDLs in the Missouri River during the
1981-1991 analysis period (table 4). The downward trends in SSDLs, FW SSDCs, and SSDL percentage of SSLs at the Missouri River at Sioux City, Iowa, for the 1976-2004 period are likely the result of downward trends in flows rather than a depletion of readily available upstream sand sources. The U.S. Army Corps of Engineers (2004) reported a 3.3-meter (m) decline in stage for a reference flow at the Gavins Point Dam outflow and at the Sioux City station between 1955 and the early 1980s. During the dry period of 1985-1991, sand loads at Sioux City were reduced and the river stage increased by $0.3 \mathrm{~m}$. A succession of high-flow years in the 1990s, however, resulted in a further 1-m decline in stage at a reference flow at this station through 2003, indicating a continued availability of source material. 

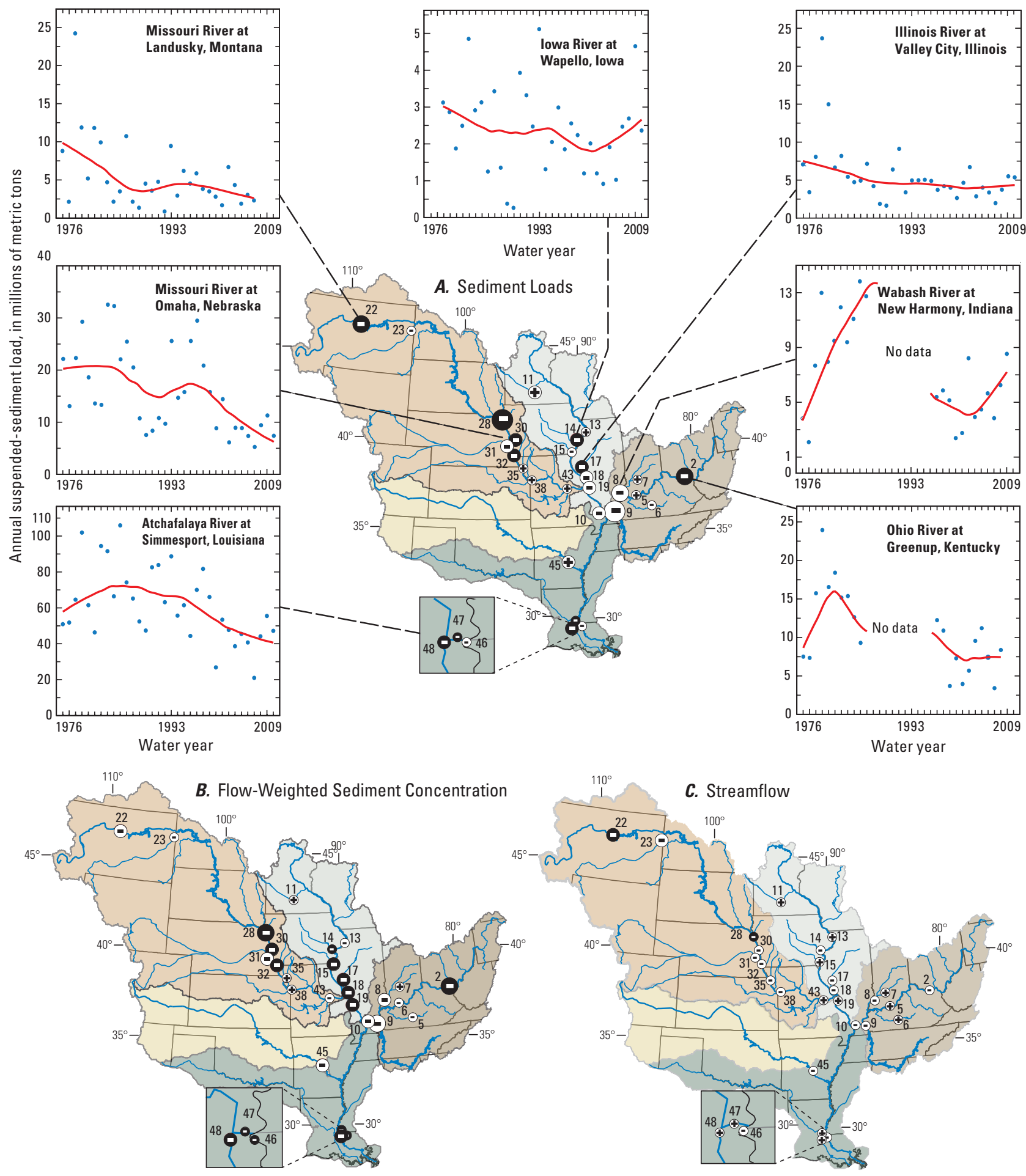

Base Map from USGS Digital Data, 1:2,000,000, 1990 Albers Equal Area Conic projection

EXPLANATION

Locally estimated scatterplot
smoothing (LOESS) fit curve
- Annual load
300 U.S.Geological Survey streamgaging
stations and identifier (table 2)

Mann-Kendall trend test, Sen slope

† p less than 0.05, upward slope $\bigoplus$ p greater than 0.05 , Upward Slope

- pless than 0.05 , downward slope

$\odot$ p greater than 0.05 , downward slope
Trend (in percent/year)

- $0-1.00$

1.01-2.00

$2.01-3.00$

Greater than 3.00

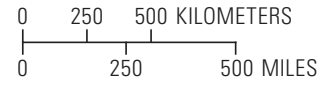

River basins

Missouri River Basin

Upper Mississippi River Basin

$\square$ Ohio River Basin

$\square$ Arkansas River Basin

Figure 7. Summary of trends in annual suspended-sediment loads, flow-weighted concentrations, and streamflows at selected U.S. Geological Survey streamgaging stations in the Mississippi River Basin, 1976-2009. 


\section{Trends in Suspended-Sediment Loads and Concentrations in the Mississippi River Basin, 1950-2009}

Table 8. Summary of analyses of monotonic trends in annual suspended-sediment loads, flow-weighted concentrations, and streamflows between 1976 and 2009 at selected Mississippi River Basin streamgaging stations.

[p-value, statistical probability level; yr, year; mg/L, milligrams per liter; $<$, less than; $\mathrm{m}^{3} / \mathrm{s}$, cubic meter per second]

\begin{tabular}{|c|c|c|c|c|c|c|c|}
\hline \multirow{2}{*}{$\begin{array}{l}\text { Short name } \\
\text { (table 2) }\end{array}$} & \multirow{2}{*}{$\begin{array}{c}\text { Map } \\
\text { reference } \\
\text { number } \\
\text { (fig. 1) }\end{array}$} & \multirow{2}{*}{$\begin{array}{l}\text { Number of } \\
\text { values used } \\
\text { in analysis }\end{array}$} & \multicolumn{4}{|c|}{ Suspended-sediment loads } & \multirow{2}{*}{$\begin{array}{c}\text { Trend (in } \\
\text { percent/ } \\
\text { yr) }\end{array}$} \\
\hline & & & $\begin{array}{l}\text { Mann-Kendall } \\
\text { tau } \\
\end{array}$ & p-value & $\begin{array}{l}\text { Sen slope (met- } \\
\text { ric tons/yr) }\end{array}$ & $\begin{array}{l}\text { Median (metric } \\
\text { tons) }\end{array}$ & \\
\hline Ohio River at Greenup Dam near Greenup, Kentucky & 2 & 21 & $-0.429^{a}$ & 0.007 & $-291,000$ & $9,560,000$ & -3.04 \\
\hline Green River at Munfordville, Kentucky & 6 & 9 & 0 & 1.00 & -110 & 318,000 & -.03 \\
\hline White River at Hazleton, Indiana & 7 & 9 & .111 & .755 & 14,400 & $2,030,000$ & .71 \\
\hline $\begin{array}{l}\text { Tennessee River at Highway } 60 \text { near Paducah, } \\
\text { Kentucky }\end{array}$ & 9 & 8 & -.357 & .266 & $-20,900$ & 461,000 & -4.53 \\
\hline Ohio River at Dam 53 Near Grand Chain, Illinois & 10 & 11 & -.236 & .350 & $-645,000$ & $40,300,000$ & -1.60 \\
\hline Minnesota River at Mankato, Minnesota & 11 & 32 & .206 & .102 & 22,300 & $1,210,000$ & 1.84 \\
\hline Mississippi River at Clinton, Iowa & 13 & 36 & .033 & .913 & 1,920 & $3,450,000$ & .06 \\
\hline Mississippi River at Saint Louis, Missouri & 19 & 34 & -.234 & .054 & $-1,640,000$ & $91,100,000$ & -1.80 \\
\hline Missouri River near Landusky, Montana & 22 & 31 & -.290 & .023 & $-162,000$ & $4,320,000$ & -3.75 \\
\hline Yellowstone River near Sidney, Montana & 23 & 11 & -.200 & .436 & $-74,300$ & $5,330,000$ & -1.39 \\
\hline Missouri River at Sioux City, Iowa & 28 & 13 & -.495 & .003 & $-363,000$ & $6,740,000$ & -5.39 \\
\hline Missouri River at Omaha, Nebraska & 30 & 19 & -.368 & .030 & $-430,000$ & $14,700,000$ & -2.93 \\
\hline Platte River at Louisville, Nebraska & 31 & 11 & -.236 & .350 & $-160,000$ & $6,200,000$ & -2.58 \\
\hline Missouri River at Nebraska City, Nebraska & 32 & 23 & -.328 & .030 & $-573,000$ & $23,100,000$ & -2.48 \\
\hline Missouri River at Saint Joseph, Missouri & 35 & 18 & .020 & .940 & 17,500 & $31,800,000$ & .06 \\
\hline Kansas River at DeSoto, Kansas & 37 & 20 & .103 & .669 & 167,000 & $41,600,000$ & .40 \\
\hline \multirow{2}{*}{ Atchafalaya River at Simmesport, Louisiana } & \multirow{2}{*}{$\begin{array}{c}\text { Map } \\
\text { reference } \\
\text { number } \\
\text { (fig. 1) }\end{array}$} & \multirow{2}{*}{$\begin{array}{l}\text { Number of } \\
\text { values used } \\
\text { in analysis }\end{array}$} & \multicolumn{4}{|c|}{ Flow-weighted suspended-sediment concentrations } & \multirow{2}{*}{$\begin{array}{c}\text { Trend (in } \\
\text { percent/ } \\
\text { yr) }\end{array}$} \\
\hline & & & $\begin{array}{c}\text { Mann-Kendall } \\
\text { tau }\end{array}$ & p-value & $\begin{array}{l}\text { Sen slope } \\
((\mathrm{mg} / \mathrm{L}) / \mathrm{yr})\end{array}$ & Median (mg/L) & \\
\hline Ohio River at Greenup Dam near Greenup, Kentucky & 2 & 21 & -0.514 & 0.001 & -4.06 & 125 & -3.25 \\
\hline Ohio River at Cannelton Dam at Cannelton, Indiana & 5 & 8 & -.048 & 1.00 & -.528 & 206 & -.26 \\
\hline Green River at Munfordville, Kentucky & 6 & 9 & -.167 & .602 & -1.34 & 116 & -1.16 \\
\hline White River at Hazleton, Indiana & 7 & 9 & .056 & .917 & .247 & 175 & .14 \\
\hline Wabash River at New Harmony, Indiana & 8 & 8 & -.429 & .174 & -3.42 & 183 & -1.87 \\
\hline Mississippi River at Clinton, Iowa & 13 & 36 & -.165 & .443 & -.756 & 65.3 & -1.16 \\
\hline Iowa River at Wapello, Iowa & 14 & 29 & -.261 & .049 & -3.12 & 231 & -1.35 \\
\hline Skunk River at Augusta, Iowa & 15 & 34 & -.362 & .003 & -18.0 & 785 & -2.29 \\
\hline Illinois River at Valley City, Illinois & 17 & 12 & -.320 & .012 & -3.29 & 200 & -1.65 \\
\hline Mississippi River below Grafton, Illinois & 18 & 24 & -.297 & .045 & -4.68 & 177 & -2.65 \\
\hline Mississippi River at Saint Louis, Missouri & 19 & 34 & -.447 & $<.001$ & -9.84 & 475 & -2.07 \\
\hline Missouri River near Landusky, Montana & 22 & 31 & -.187 & .144 & -8.77 & 534 & -1.64 \\
\hline Yellowstone River near Sidney, Montana & 23 & 11 & -0.127 & 0.640 & -8.37 & 691 & -1.21 \\
\hline
\end{tabular}


Table 8. Summary of analyses of monotonic trends in annual suspended-sediment loads, flow-weighted concentrations, and streamflows between 1976 and 2009 at selected Mississippi River Basin streamgaging stations.-Continued

[p-value, statistical probability level; yr, year; mg/L, milligrams per liter; <, less than; $\mathrm{m}^{3} / \mathrm{s}$, cubic meter per second]

\begin{tabular}{|c|c|c|c|c|c|c|c|}
\hline \multirow[b]{2}{*}{ Short name } & \multirow{2}{*}{$\begin{array}{l}\text { Map } \\
\text { reference } \\
\text { number } \\
\text { (fig. 1) }\end{array}$} & \multirow[b]{2}{*}{$\begin{array}{l}\text { Number of } \\
\text { values used } \\
\text { in analysis }\end{array}$} & \multicolumn{4}{|c|}{ Flow-weighted suspended-sediment concentrations } & \multirow[b]{2}{*}{$\begin{array}{l}\text { Trend (in } \\
\text { percent/yr) }\end{array}$} \\
\hline & & & $\begin{array}{l}\text { Mann-Kendall } \\
\text { tau }\end{array}$ & p-value & $\begin{array}{l}\text { Sen slope } \\
((\mathrm{mg} / \mathrm{L}) / \mathrm{yr})\end{array}$ & $\begin{array}{l}\text { Median } \\
(\mathrm{mg} / \mathrm{L})\end{array}$ & \\
\hline Missouri River at Sioux City, Iowa & 28 & 13 & -.547 & $<.001$ & -8.32 & 254 & -3.27 \\
\hline Missouri River at Omaha, Nebraska & 30 & 19 & -.392 & .021 & -8.50 & 493 & -1.72 \\
\hline Platte River at Louisville, Nebraska & 31 & 11 & -.273 & .276 & -21.7 & 831 & -2.61 \\
\hline Missouri River at Nebraska City, Nebraska & 32 & 23 & -.336 & .027 & -8.93 & 632 & -1.41 \\
\hline Missouri River at Saint Joseph, Missouri & 35 & 18 & .007 & 1.00 & .587 & 743 & .08 \\
\hline Kansas River at DeSoto, Kansas & 37 & 20 & .026 & .951 & 1.19 & 830 & .14 \\
\hline Missouri River at Hermann, Missouri & 43 & 18 & -.033 & .880 & -1.24 & 657 & -.19 \\
\hline $\begin{array}{l}\text { Arkansas River at David D. Terry Lock and Dam below } \\
\text { Little Rock, Arkansas }\end{array}$ & 45 & 11 & -.309 & .213 & -1.45 & 59.6 & -2.43 \\
\hline Mississippi River at Tarbert Landing, Mississippi & 46 & 34 & -.259 & .033 & -1.85 & 268 & -.69 \\
\hline Old River Outflow Channel near Knox Landing, Louisiana & 47 & 34 & -.444 & $<.001$ & -2.91 & 238 & -1.22 \\
\hline \multirow[t]{3}{*}{ Atchafalaya River at Simmesport, Louisiana } & 48 & 34 & -.497 & $<.001$ & $-\mathbf{5 . 5 5}$ & 318 & -1.75 \\
\hline & \multirow{2}{*}{$\begin{array}{c}\text { Map } \\
\text { reference } \\
\text { number } \\
\text { (fig. 1) }\end{array}$} & \multirow[b]{2}{*}{$\begin{array}{l}\text { Number of } \\
\text { values used } \\
\text { in analysis }\end{array}$} & \multicolumn{4}{|c|}{ Streamflow } & \multirow[b]{2}{*}{$\begin{array}{l}\text { Trend (in } \\
\text { percent/yr) }\end{array}$} \\
\hline & & & $\begin{array}{l}\text { Mann-Kendall } \\
\text { tau }\end{array}$ & p-value & $\begin{array}{l}\text { Sen slope } \\
\left(\left(\mathrm{m}^{3} / \mathrm{s}\right) / \mathrm{yr}\right)\end{array}$ & $\begin{array}{l}\text { Median } \\
\left(\mathrm{m}^{3} / \mathrm{s}\right)\end{array}$ & \\
\hline Ohio River at Greenup Dam near Greenup, Kentucky & 2 & 21 & -0.038 & 0.838 & -3.03 & 2370 & -0.13 \\
\hline Ohio River at Cannelton Dam at Cannelton, Indiana & 5 & 8 & .238 & .548 & 6.61 & 3,970 & .17 \\
\hline Green River at Munfordville, Kentucky & 6 & 9 & 0 & 1.00 & .022 & 82.1 & .03 \\
\hline White River at Hazleton, Indiana & 7 & 9 & .278 & .348 & 4.02 & 408 & .99 \\
\hline Wabash River at New Harmony, Indiana & 8 & 8 & -.071 & .902 & -.467 & 1,020 & -.05 \\
\hline Tennessee River at Highway 60 near Paducah, Kentucky & 9 & 8 & -.429 & .174 & -23.2 & 1,640 & -1.42 \\
\hline Ohio River at Dam 53 Near Grand Chain, Illinois & 10 & 11 & -.091 & .732 & -32.0 & 8,480 & -.38 \\
\hline Minnesota River at Mankato, Minnesota & 11 & 32 & .130 & .286 & 1.68 & 142 & 1.18 \\
\hline Mississippi River at Clinton, Iowa & 13 & 36 & .187 & .381 & 16.8 & 1,720 & .98 \\
\hline Iowa River at Wapello, Iowa & 14 & 29 & -.143 & .285 & -2.27 & 260 & -.87 \\
\hline Skunk River at Augusta, Iowa & 15 & 34 & .037 & .767 & .271 & 85.9 & .32 \\
\hline Illinois River at Valley City, Illinois & 17 & 12 & -.058 & .659 & -2.17 & 740 & -.29 \\
\hline Mississippi River below Grafton, Illinois & 18 & 24 & -.065 & .673 & -9.28 & 3,550 & -.26 \\
\hline Mississippi River at Saint Louis, Missouri & 19 & 34 & .034 & .790 & 7.55 & 6,240 & .12 \\
\hline Missouri River near Landusky, Montana & 22 & 31 & -.372 & .004 & -4.74 & 232 & -2.04 \\
\hline Yellowstone River near Sidney, Montana & 23 & 11 & -.346 & .161 & -5.45 & 265 & -2.06 \\
\hline Missouri River at Sioux City, Iowa & 28 & 13 & -.379 & .021 & -11.0 & 784 & -1.40 \\
\hline Missouri River at Omaha, Nebraska & 30 & 19 & -.275 & .108 & -10.8 & 1,020 & -1.05 \\
\hline Platte River at Louisville, Nebraska & 31 & 11 & -.018 & 1.00 & -1.06 & 166 & -.64 \\
\hline Missouri River at Nebraska City, Nebraska & 32 & 23 & -.296 & .051 & -13.0 & 1,080 & -1.21 \\
\hline Missouri River at Saint Joseph, Missouri & 35 & 18 & -.163 & .363 & -6.76 & 1,250 & -.54 \\
\hline Kansas River at DeSoto, Kansas & 37 & 20 & -.026 & .951 & -2.05 & 1,460 & -.14 \\
\hline Missouri River at Hermann, Missouri & 43 & 18 & .111 & .545 & 9.79 & 2,330 & .42 \\
\hline $\begin{array}{l}\text { Arkansas River at David D. Terry Lock and Dam below } \\
\text { Little Rock, Arkansas }\end{array}$ & 45 & 11 & -.200 & .436 & -15.2 & 1,130 & -1.35 \\
\hline Mississippi River at Tarbert Landing, Mississippi & 46 & 34 & -.037 & .767 & -24.3 & 14,700 & -.17 \\
\hline Old River Outflow Channel near Knox Landing, Louisiana & 47 & 34 & .119 & .328 & 16.6 & 4,170 & .40 \\
\hline Atchafalaya River at Simmesport, Louisiana & 48 & 34 & .023 & .859 & 5.71 & 6,410 & .09 \\
\hline
\end{tabular}

${ }^{a}$ Values in bold are statistically significant $(\mathrm{p}<0.05)$. 


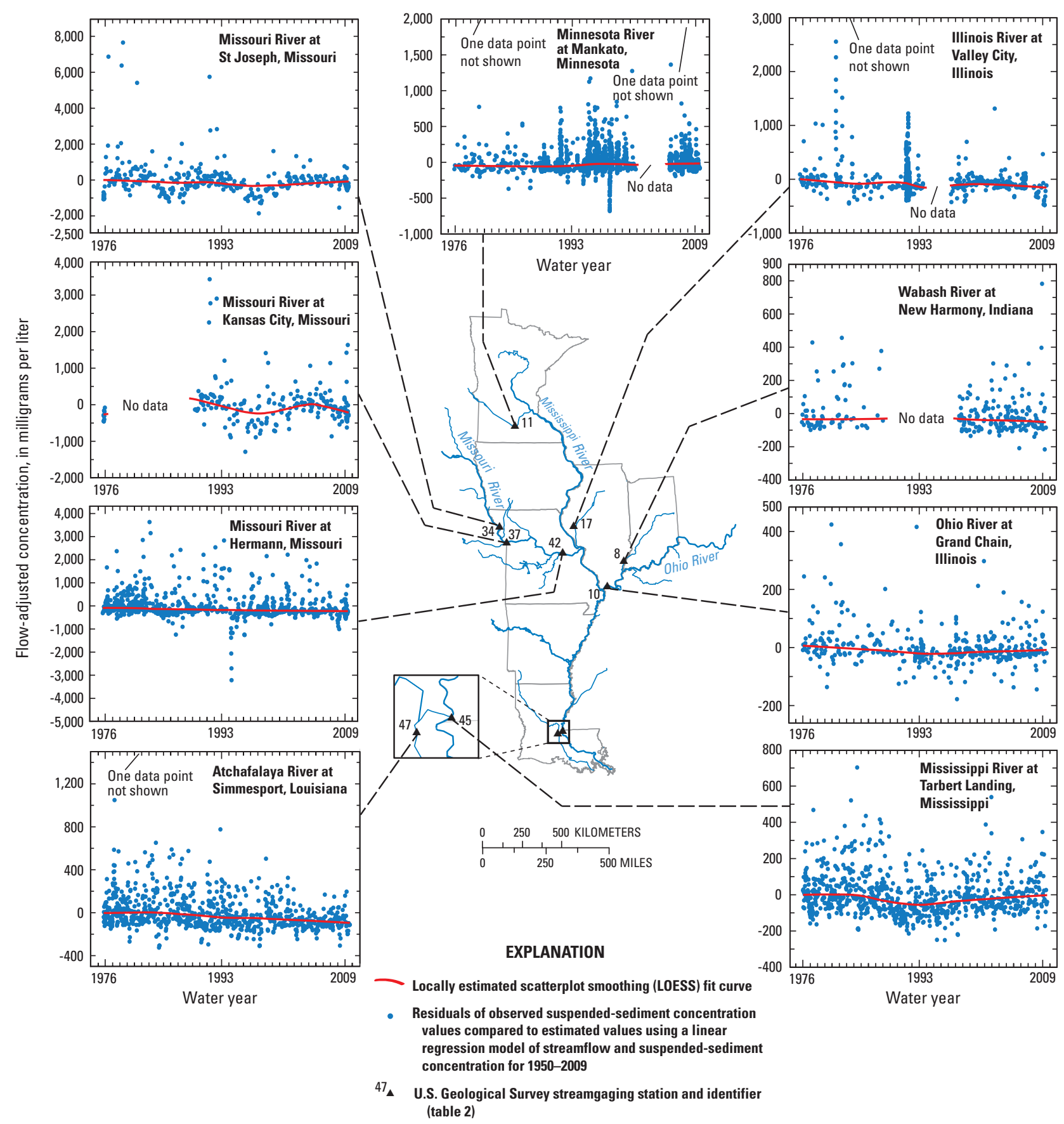

Figure 8. Summary of temporal variations in flow-adjusted sediment concentrations for selected U.S. Geological Survey streamgaging stations in the Mississippi River Basin, 1976-2009.

There were downward changes in FA SSDCs at four of five Missouri River Basin stations during 1976-2004 (fig. 6), whereas FA SSDCs at the remaining station were relatively unchanged. The FA SSDCs at the Missouri River at Saint Joseph, Kansas City, and Hermann, Missouri (fig. 6), showed small but steady declines during 1976-2004. There was, however, a period of primarily negative FA SSDCs, that is, lower measured concentrations for a particular flow than would be expected from an overall streamflow-SSC relation, at the Missouri River at Kansas City and Hermann, Missouri, between 1993 and 1996 (fig. 6). The declines in FA SSDCs were short term and were not expressed in the fitted LOESS curve. The subtle decline in FA SSDCs at the Platte River at Louisville, Nebraska, station may be the result of high flows in 1987, 1993, and 1995, but the apparent effects in the SSDCstreamflow relation were temporary. There was a subtle "dip" in FA SSDCs between 1988 and 1997 at the Platte River at Louisville, Nebraska, station but no apparent changes in the FA SSDCs at the Yellowstone River at Sidney, Montana. 
Table 9. Summary of analyses of monotonic trends in annual suspended-sand loads, flow-weighted suspended-sand concentrations, and suspended-sand load as a percentage of total suspended-sediment loads between 1976 and 2004 at selected Missouri River and lower Mississippi River Basin stations.

[p-value, statistical probability level; <, less than; yr, year; mg/L, milligrams per liter; $\mathrm{m}^{3} / \mathrm{s}$, cubic meter per second]

\begin{tabular}{|c|c|c|c|c|c|c|c|}
\hline \multirow[b]{2}{*}{ USGS station name) } & \multirow{2}{*}{$\begin{array}{l}\text { Map } \\
\text { reference } \\
\text { number } \\
\text { (fig. 1) }\end{array}$} & \multirow{2}{*}{$\begin{array}{l}\text { Number of } \\
\text { values used } \\
\text { in analysis }\end{array}$} & \multicolumn{4}{|c|}{ Suspended-sand load } & \multirow{2}{*}{$\begin{array}{c}\text { Trend (in } \\
\text { percent/ } \\
\text { yr) }\end{array}$} \\
\hline & & & $\begin{array}{l}\text { Mann-Kendall } \\
\text { tau }\end{array}$ & p-value & $\begin{array}{l}\text { Sen slope } \\
\text { (metric tons) }\end{array}$ & $\begin{array}{l}\text { Median (met- } \\
\text { ric tons) }\end{array}$ & \\
\hline $\begin{array}{l}\text { Yellowstone River near Sidney, Mon- } \\
\text { tana }\end{array}$ & 23 & 10 & -0.289 & 0.283 & $-85,800$ & $1,750,000$ & -4.90 \\
\hline $\begin{array}{l}\text { Missouri River at Saint Joseph, Mis- } \\
\text { souri }\end{array}$ & 35 & 15 & $-.448^{a}$ & .023 & $-333,000$ & $11,300,000$ & -2.95 \\
\hline Missouri River at Kansas City, Missouri & 38 & 13 & -.5 & .02 & $-379,000$ & $14,200,000$ & -2.67 \\
\hline Missouri River at Hermann, Missouri & 43 & 15 & -.181 & .373 & $-105,000$ & $12,800,000$ & -.82 \\
\hline $\begin{array}{l}\text { Mississippi River at Tarbert Landing, } \\
\text { Mississippi }\end{array}$ & 46 & 30 & .03 & .83 & 101,000 & $24,900,000$ & .41 \\
\hline $\begin{array}{l}\text { Old River Outflow Channel near Knox } \\
\text { Landing, Louisiana }\end{array}$ & 47 & 30 & -.136 & .301 & $-83,300$ & $5,140,000$ & -1.62 \\
\hline $\begin{array}{l}\text { Atchafalaya River at Simmesport, } \\
\text { Louisiana }\end{array}$ & 48 & 30 & .03 & .83 & 50,700 & $12,600,000$ & .40 \\
\hline \multirow[b]{2}{*}{ USGS station name } & \multirow{2}{*}{$\begin{array}{l}\text { Map } \\
\text { reference } \\
\text { number } \\
\text { (fig. 1) }\end{array}$} & \multirow{2}{*}{$\begin{array}{l}\text { Number of } \\
\text { values used } \\
\text { in analysis }\end{array}$} & \multicolumn{4}{|c|}{ Flow-weighted suspended-sand concentration } & \multirow{2}{*}{$\begin{array}{c}\text { Trend (in } \\
\text { percent/ } \\
\text { yr) }\end{array}$} \\
\hline & & & $\begin{array}{l}\text { Mann-Kendall } \\
\text { tau }\end{array}$ & p-value & $\begin{array}{l}\text { Sen slope } \\
\text { (mg/L) }\end{array}$ & $\begin{array}{l}\text { Median } \\
\text { (mg/L) }\end{array}$ & \\
\hline $\begin{array}{l}\text { Yellowstone River near Sidney, Mon- } \\
\text { tana }\end{array}$ & 23 & 10 & -0.244 & 0.371 & -5.1 & 192 & -2.66 \\
\hline $\begin{array}{l}\text { Missouri River at Saint Joseph, Mis- } \\
\text { souri }\end{array}$ & 35 & 15 & -.638 & .001 & -7.4 & 291 & -2.54 \\
\hline Missouri River at Kansas City, Missouri & 38 & 13 & -.795 & $<.001$ & -8.09 & 251 & -3.22 \\
\hline Missouri River at Hermann, Missouri & 43 & 15 & -.505 & .01 & -3.74 & 207 & -1.81 \\
\hline $\begin{array}{l}\text { Mississippi River at Tarbert Landing, } \\
\text { Mississippi }\end{array}$ & 46 & 30 & .025 & .858 & .151 & 53.3 & .28 \\
\hline $\begin{array}{l}\text { Old River Outflow Channel near Knox } \\
\text { Landing, Louisiana }\end{array}$ & 47 & 30 & -.145 & .269 & -.466 & 37.6 & -1.24 \\
\hline \multirow[t]{3}{*}{$\begin{array}{l}\text { Atchafalaya River at Simmesport, } \\
\text { Louisiana }\end{array}$} & 48 & 30 & .053 & .695 & .288 & 62.3 & 0.46 \\
\hline & \multirow{2}{*}{$\begin{array}{c}\text { Map } \\
\text { reference } \\
\text { number } \\
\text { (fig. 1) }\end{array}$} & \multirow{2}{*}{$\begin{array}{l}\text { Number of } \\
\text { values used } \\
\text { in analysis }\end{array}$} & \multicolumn{4}{|c|}{ Suspended-sand load percentage of uspended-sand load } & \multirow{2}{*}{$\begin{array}{c}\text { Trend (in } \\
\text { percent/ } \\
\text { yr) }\end{array}$} \\
\hline & & & $\begin{array}{l}\text { Mann-Kendall } \\
\text { tau }\end{array}$ & p-value & $\begin{array}{l}\text { Sen slope } \\
\left(\mathrm{m}^{3} / \mathrm{s}\right)\end{array}$ & Median ( $\left.\mathrm{m}^{3} / \mathrm{s}\right)$ & \\
\hline $\begin{array}{l}\text { Yellowstone River near Sidney, Mon- } \\
\text { tana }\end{array}$ & 23 & 10 & 0.244 & 0.371 & 0.524 & 17.6 & 2.98 \\
\hline $\begin{array}{l}\text { Missouri River at Saint Joseph, Mis- } \\
\text { souri }\end{array}$ & 35 & 15 & -.695 & $<.001$ & -1.09 & 36.9 & -2.95 \\
\hline Missouri River at Kansas City, Missouri & 38 & 13 & -.821 & $<.001$ & -.832 & 32.9 & -2.53 \\
\hline Missouri River at Hermann, Missouri & 43 & 15 & -.448 & .023 & -.744 & 28.0 & -2.66 \\
\hline $\begin{array}{l}\text { Mississippi River at Tarbert Landing, } \\
\text { Mississippi }\end{array}$ & 46 & 30 & .214 & .099 & .214 & 19.0 & 1.13 \\
\hline $\begin{array}{l}\text { Old River Outflow Channel near Knox } \\
\text { Landing, Louisiana }\end{array}$ & 47 & 30 & .03 & .83 & 0 & 15.0 & 0 \\
\hline $\begin{array}{l}\text { Atchafalaya River at Simmesport, } \\
\text { Louisiana }\end{array}$ & 48 & 30 & .253 & .051 & .435 & 21.0 & 2.07 \\
\hline
\end{tabular}

${ }^{a}$ Values in bold are statistically significant $(\mathrm{p}<0.05)$. 



Figure 9. Summary of trends in annual suspended-sediment loads, flow-weighted concentrations, and streamflows at selected U.S. Geological Survey streamgaging stations in the Mississippi River Basin, 1998-2009. 


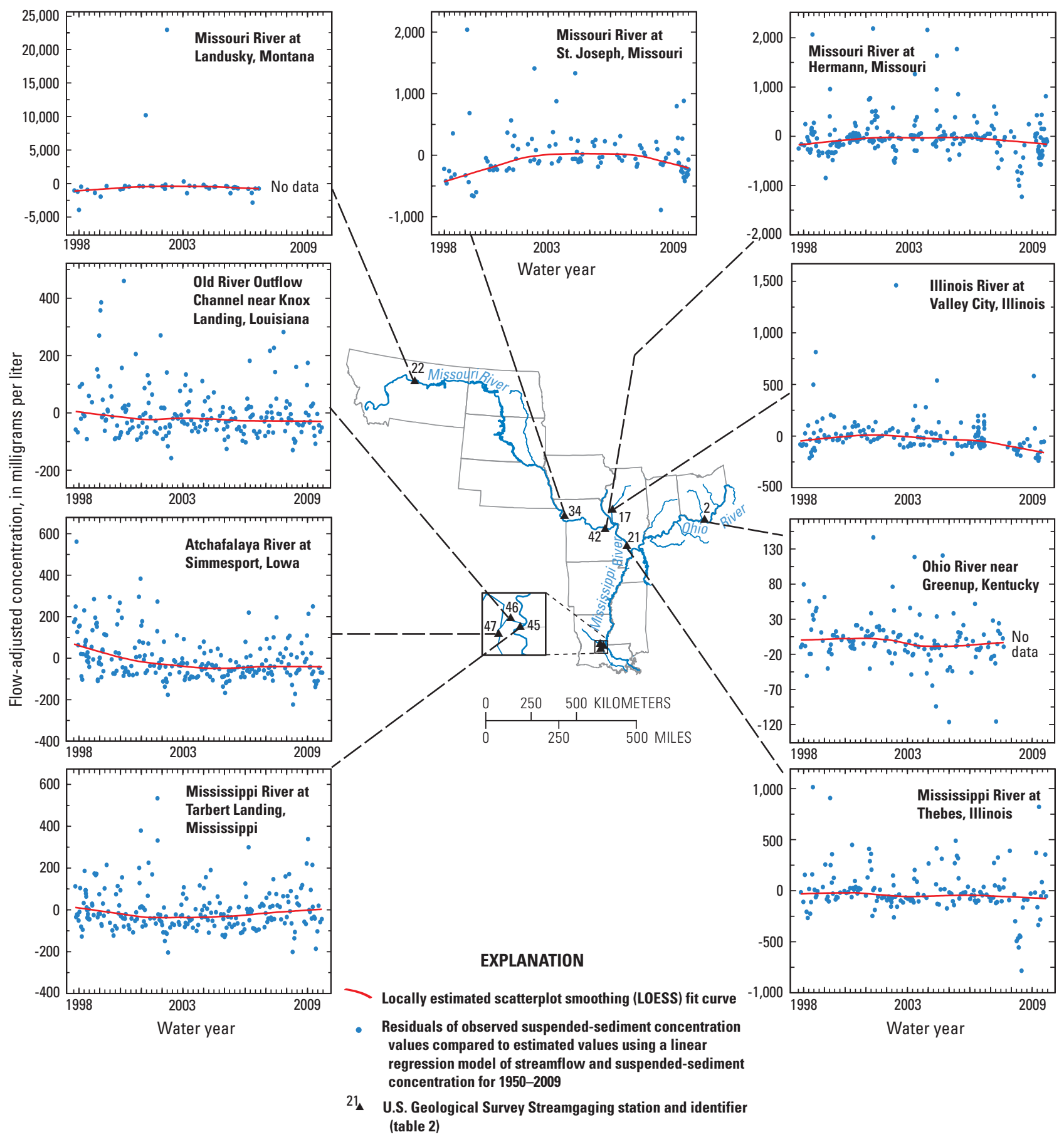

Figure 10. Summary of temporal variations in flow-adjusted sediment concentrations for selected U.S. Geological Survey streamgaging stations in the Mississippi River Basin, 1998-2009.

\section{Suspended Sediment 1998-2009}

Analyses of monotonic trends in SSLs, FW SSCs, and streamflows over a recent (1998-2009) post-channel modification period in the subbasins indicate that slopes of these constituents were generally downward but few temporal changes were significant (fig. 9, table 10). A significant downward trend in SSLs was indicated for the Missouri River at Sioux
City, Iowa, but temporal changes in SSLs were not significant at any of the remaining 17 stations. The downward trends in FW SSCs were significant during the 12-year period only at the Skunk River at Augusta, Iowa, in the upper Mississippi River Basin and the Old River Outflow station in Louisiana. Significant downward trends in streamflow were determined for two Missouri River stations including the Missouri River at Sioux City, Iowa, and at Omaha, Nebraska. 
Table 10. Summary of analyses of monotonic trends in annual suspended-sediment loads, flow-weighted suspended-sediment concentrations, and streamflows between 1998 and 2009 at selected Mississippi River Basin streamgaging stations.

[p-value, statistical probability level; yr, year; $\mathrm{mg} / \mathrm{L}$, milligrams per liter; $\mathrm{m}^{3} / \mathrm{s}$, cubic meter per second]

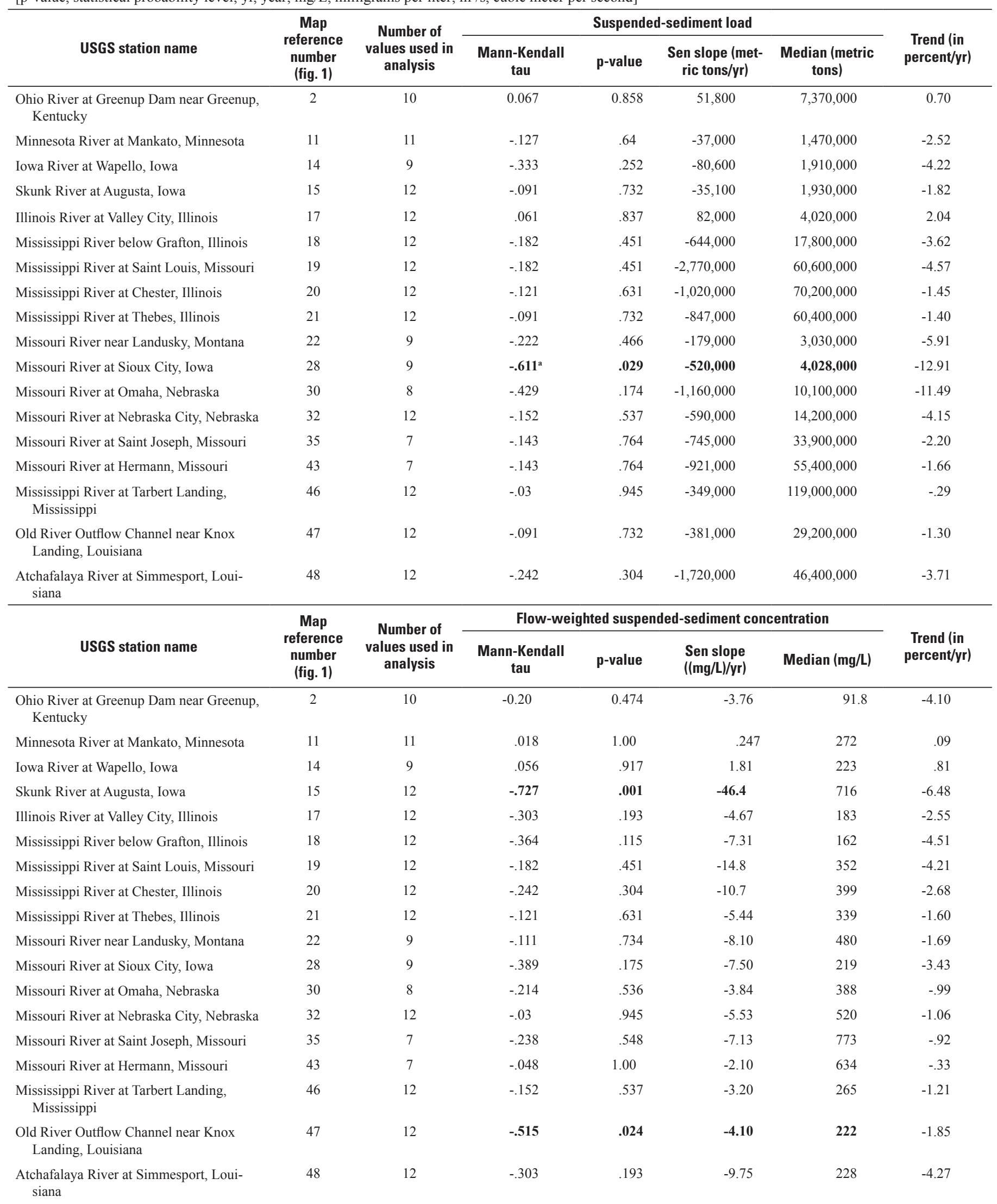


Table 10. Summary of analyses of monotonic trends in annual suspended-sediment loads, flow-weighted suspended-sediment concentrations, and streamflows between 1998 and 2009 at selected Mississippi River Basin streamgaging stations.-Continued

[p-value, statistical probability level; yr, year; $\mathrm{mg} / \mathrm{L}$, milligrams per liter; $\mathrm{m}^{3} / \mathrm{s}$, cubic meter per second]

\begin{tabular}{|c|c|c|c|c|c|c|c|}
\hline \multirow[b]{2}{*}{ USGS station name } & \multirow{2}{*}{$\begin{array}{c}\text { Map } \\
\text { reference } \\
\text { number } \\
\text { (fig. 1) }\end{array}$} & \multirow{2}{*}{$\begin{array}{c}\text { Number of } \\
\text { values used in } \\
\text { analysis }\end{array}$} & \multicolumn{4}{|c|}{ Streamflow } & \multirow[b]{2}{*}{$\begin{array}{l}\text { Trend (in per } \\
\text { cent/yr) }\end{array}$} \\
\hline & & & $\begin{array}{l}\text { Mann-Kendall } \\
\text { tau }\end{array}$ & p-value & $\begin{array}{l}\text { Sen slope } \\
\left(\left(\mathrm{m}^{3} / \mathrm{s}\right) / \mathrm{yr}\right)\end{array}$ & Median $\left(\mathrm{m}^{3} / \mathrm{s}\right)$ & \\
\hline $\begin{array}{l}\text { Ohio River at Greenup Dam near Greenup, } \\
\text { Kentucky }\end{array}$ & 2 & 10 & 0.378 & 0.152 & 118 & 2,310 & 5.11 \\
\hline Minnesota River at Mankato, Minnesota & 11 & 11 & 0 & 1.00 & .393 & 133 & .30 \\
\hline Iowa River at Wapello, Iowa & 14 & 9 & -.389 & .175 & -22.1 & 204 & -10.82 \\
\hline Skunk River at Augusta, Iowa & 15 & 12 & .152 & .537 & 3.06 & 87 & 3.52 \\
\hline Illinois River at Valley City, Illinois & 17 & 12 & .212 & .373 & 27.8 & 677 & 4.10 \\
\hline Mississippi River below Grafton, Illinois & 18 & 12 & -.03 & .945 & -18.1 & 3,410 & -.53 \\
\hline Mississippi River at Saint Louis, Missouri & 19 & 12 & -.061 & .837 & -37.2 & 5,480 & -.68 \\
\hline Mississippi River at Chester, Illinois & 20 & 12 & -.03 & .945 & -23.5 & 5,700 & -.41 \\
\hline Mississippi River at Thebes, Illinois & 21 & 12 & -.061 & .837 & -16.6 & 6,040 & -.28 \\
\hline Missouri River near Landusky, Montana & 22 & 9 & -.222 & .466 & -4.84 & 170 & -2.84 \\
\hline Missouri River at Sioux City, Iowa & 28 & 9 & -.722 & .009 & -49.2 & 659 & -7.47 \\
\hline Missouri River at Omaha, Nebraska & 30 & 8 & -.786 & .009 & -76.6 & 812 & -9.43 \\
\hline Missouri River at Nebraska City, Nebraska & 32 & 12 & -.364 & .115 & -37.4 & 955 & -3.91 \\
\hline Missouri River at Saint Joseph, Missouri & 35 & 7 & -.143 & .764 & -18.1 & 1,130 & -1.6 \\
\hline Missouri River at Hermann, Missouri & 43 & 7 & -.048 & 1.00 & -6.80 & 2,410 & -.28 \\
\hline $\begin{array}{l}\text { Mississippi River at Tarbert Landing, } \\
\text { Mississippi }\end{array}$ & 46 & 12 & 0 & 1.00 & .871 & 15,000 & .01 \\
\hline $\begin{array}{l}\text { Old River Outflow Channel near Knox } \\
\text { Landing, Louisiana }\end{array}$ & 47 & 12 & .091 & .732 & 25.0 & 4,450 & .56 \\
\hline $\begin{array}{l}\text { Atchafalaya River at Simmesport, Loui- } \\
\text { siana }\end{array}$ & 48 & 12 & 0 & 1.00 & 1.89 & 6,430 & .03 \\
\hline
\end{tabular}

${ }^{a}$ Values in bold are statistically significant $(\mathrm{p}<0.05)$.

The downward temporal changes in streamflow could account for the SSL declines as temporal relations in FA SSCs at most stations did not show substantial corresponding changes in the sediment transport relations (fig. 10). Exceptions included a decline in the sediment concentration for a given flow at the Atchafalaya River at Simmesport, Louisiana, indicating an adjustment to limitations in sediment supply, and an increase in the sediment concentration for a given flow at the Missouri River at Saint Joseph, Missouri, station during an apparent sediment supply recovery period following the 1993 and 1995 floods.

\section{Summary}

Of the four primary contributing subbasins to the lower Mississippi River, the Missouri River provided the greatest median suspended-sediment load followed by the Ohio River, upper Mississippi, and Arkansas Rivers during the 1976-2009 analysis period. The Missouri River provided the largest annual suspended-sediment loads during 26 of the 34 years analyzed, and the Ohio River transported the largest annual loads during the remaining 8 years. Overall, sediment transport in the lower Mississippi River is most closely correlative with the contributions of suspended sediment from the Missouri River Basin.

Annual suspended-sediment loads were computed for gaged tributary streams within the Missouri, Ohio, and upper Mississippi Basins to further determine major sediment-contributing sources within the subbasins. The Grand River near Sumner, Missouri and the Platte River at Louisville, Nebraska had the largest median annual loads within the Missouri River Basin. The Wabash River provided the largest sediment contribution to the Ohio River, whereas the Illinois River was the largest sediment contributor to the upper Mississippi River.

The largest contributor of suspended sand to the lower Missouri River between 1981 and 1991 was estimated to be sand from the main-stem reach between Gavins Point Dam, South Dakota, and Sioux City, Iowa, followed by contributions from the Platte River in Nebraska. If additional potential diversions that substantially reduce flows take place in the Platte River there likely will be a substantial reduction in sand loads from this primary tributary.

Results of step-trend analyses to examine changes in annual loads, concentrations, and streamflows between the 
pre- (pre-1953) and post- (post-1967) Missouri River mainstem impoundment periods indicated statistically significant declines in loads and concentrations at most stations. The greatest difference in median sediment loads between the two periods (-99.8 percent) was recorded at the Missouri River at Yankton, South Dakota, about 8 kilometers downstream from the most downstream main-stem impoundment. The difference of about 126 million metric tons between the pre-1953 and post- 1967 periods at this station provides a median annual estimate of sediment trapped by the upstream reservoirs. This represents about 56 percent of the median annual load decline of 224 million metric tons at Hermann, Missouri in the postimpoundment period. The remaining 98 million metric tons, or 44 percent, of the Hermann load reduction can be attributed to other factors including reductions in sediment from tributaries. About 47 percent of the post-1967 sediment load reduction of the lower Mississippi River (Mississippi River at Tarbert Landing, Mississippi, and the Atchafalaya River at Simmesport, Louisiana) could be accounted for by post-impoundment reductions from the Missouri River at Hermann, Missouri.

The sediment transport regimes of all five major subbasins within the Mississippi River Basin have been affected by channel modifications, navigation structures, and main-stem or tributary impoundments. Changes in suspended-sediment and suspended-sand loads and concentrations generally were downward for the 60-, 34-, and 12-year periods analyzed in this study. The downward trend in sediment loads began before the construction of main-stem impoundments on the Missouri River, but the abrupt and extensive decline in sediment transport following the closure of Fort Randall Dam in 1952 was the single largest event accelerating the decline in sediment from the Mississippi River Basin. The downward trend in sediment transport at Missouri River and downstream Mississippi River stations has continued since the completion of the Missouri River main-stem impoundments.

The results of 1950-2009 trend analyses indicate that declines in suspended-sediment loads and flow-weighted concentrations were widespread throughout the Missouri and lower Mississippi River Basin stations. A decrease in flowadjusted suspended-sediment concentrations at Missouri and Arkansas River stations in the 1960s and 1970s indicated that less suspended material was being transported for a given flow condition and likely correspond to adjustments in the sediment conveyance system in these rivers from a transport-limited system to a supply-limited system following the construction of impoundments.

There were larger declines in suspended-sediment loads and concentrations than sand loads and concentrations in the post-impoundment period at several stations in the Missouri River Basin and the most downstream station on the Mississippi River. A larger decline in silt and clay fractions of sediment transport in the system could possibly reflect the effects of conservation practices in the basin that would target topsoil containing more silt and clay than sand.

All significant trends in suspended-sediment loads and flow-weighted concentrations during the 1976-2009 period were downward and included stations within each major subbasin in the Mississippi River Basin except the Arkansas River Basin. The temporal changes in flow-adjusted suspended-sediment concentrations during the 1976-2009 period indicated there were substantial effects of the 1993 and 1995 floods on sediment transport at the Missouri River at Saint Joseph and Kansas City, Missouri, stations. The downward changes in flow-adjusted concentrations recovered at both stations by about 2003.

The majority of Mississippi River Basin stations also showed downward but nonsignificant temporal changes in suspended-sediment loads, concentrations, and streamflows during the post-channel modification analysis period of 19982009. The downward temporal changes in streamflows during the analysis period likely account for most of the declines in loads and concentrations.

\section{References Cited}

Beach, T., 1994, The fate of eroded soil: Sediment sinks and sediment budgets of agrarian landscapes in southern Minnesota, 1851-1988: Annals of the Association of American Geographers, v. 84, no.1, p. 5-28.

Biedenharn, D.S., Thorne, C.R., and Watson, C.C., 2000, Recent morphological evolution of the Lower Mississippi River: Geomorphology, v. 34, p. 227-249.

Blevins, D.W., 2006, The response of suspended sediment, turbidity, and velocity to historical alterations of the Missouri River: U.S. Geological Survey Circular 1301, 8 p.

Cleveland, W.S., and Devlin, S.J., 1988, Locally weighted regression-An approach to regression analysis by local fitting: Journal of the American Statistical Association, v. 83, p. 596-610.

Galat, D.L., Berry, C.R., Jr., Peters, E.J., and White, R.G., 2005, Missouri River Basin, in Benke, A.C., and Cushing, C.E., eds., chap. 10, Rivers of North America: Oxford, U.K., Elsevier, p. 427-480.

Gaeuman, D., and Jacobson, R.B., 2007, Field assessment of alternative bedload transport estimators: Journal of Hydraulic Engineering, v. 133, p. 1,319-1,328.

Gilliom, R.J., Hamilton, P.A., and Miller, T.L., 2001, The National Water-Quality Assessment Program-Entering a new decade of investigations: U.S. Geological Survey Fact Sheet $071-01,6 \mathrm{p}$.

Heimann, D.C., Rasmussen, P.P., Cline, T.L., Pigue, L.M., and Wagner, H.R., 2010, Characteristics of sediment data and annual suspended-sediment loads and yields for selected lower Missouri River mainstem and tributary stations, 1976-2008: U.S. Geological Survey Data Series 530, 58 p., accessed September, 2010 at $h t t p: / / p u b s . u s g s . g o v / d s / 530 /$. 
Heimann, D.C., Cline, T.L., and Glaspie, L.M., 2011, Data used in analyses of suspended-sediment and suspended-sand concentrations and loads for selected streams in the Mississippi River Basin: U.S. Geological Survey Data Report 593, $6 \mathrm{p}$.

Holmes, R.R., Jr., 1996, Sediment transport in the lower Missouri and the central Mississippi Rivers, June 26 through September 14, 1993: U.S. Geological Survey Circular 1120-I, 23 p.

Hoos, A.B., Robinson, J.A., Aycock, R.A., Knight, R.R., and Woodside, M.D., 2000, Sources, instream transport, and trends of nitrogen, phosphorus, and sediment in the lower Tennessee River Basin, 1980-96: U.S. Geological Survey Water-Resources Investigations Report 99-4139, 96 p.

Horowitz, A.J., 2010, A quarter century of declining suspended sediment fluxes in the Mississippi River and the effect of the 1993 flood: Hydrological Processes, v. 24, p.13-34.

Jacobson, R.B., Blevins, D.W., and Bitner, C.J., 2009, Sediment regime constraints on river restoration-An example from the lower Missouri River: Geological Society of America Special Papers 451, p. 1-22.

Karns, D.R., Pyron, M., and Simon, T.P., 2006, The Wabash River Symposium: Proceedings of the Indiana Academy of Science, v. 115 , no. 2, p. 79-81.

Kendall, M.G., 1975, Rank Correlation Methods, 4th ed.: Charles Griffin, London, 196 p.

Keown, M.P., Dardeau, E.A., Jr., and Causey, E.M., 1981, Characterization of the suspended-sediment regime and bed-material gradation of the Mississippi River Basin: U.S. Army Corps of Engineers, Waterway experiment Station, Report 1, Potamology Program, $62 \mathrm{p}$.

Keown, M.P., Dardeau, E.A., Jr., and Causey, E.M., 1986, Historic trends in the sediment flow regime of the Mississippi River: Water Resources Research, v. 22, p. 1,555-1,564.

Kesel, R.H., 1988, The decline in the suspended sediment load of the lower Mississippi River and its influence on adjacent wetlands: Environmental Geology and Water Sciences, v. 11, p. $271-281$.

Kesel, R.H., 1989, The role of the Mississippi River in wetland loss in southeastern Louisiana, USA: Environmental Geology and Water Sciences, v. 13, p. 183-193.

Knox, J.C., 1977, Human impacts on Wisconsin stream channels: Annals of the Association of American Geographers, v. 62 , no. 3 , p. $401-410$.

Knox, J.C. 2007, The Mississippi River system, in A. Gupta ed., Large Rivers - Geomorphology and Management,: Chichester, U.K., John Wiley and Sons, p. 145-182.
Lorenz, D.L., Robertson, D.M., Hall, D.W., and Saad, D.A., 2009, Trends in streamflow and nutrient and suspenedsediment concentrations and loads in the upper Mississippi, Ohio, Red, and Great Lakes River Basins, 1975-2004: U.S. Geological Survey Scientific Investigations Report 20085213, 82 p.

Mann, H.B., 1945, Non-parametric test against trend: Econometrica, v. 13, p. 245-259.

Meade, R.H., 1995, Setting — geology, hydrology, sediments, and engineering of the Mississippi River. in Meade, R.H, ed., Contaminants in the Mississippi River, 1987-92: U.S. Geological Survey Circular 1133, p. 13-30.

Meade, R.H., 2004, Engineering works and their effects on movement and storage of sediment in Mississippi River and its major tributaries in Hu,C., and Tan,Y. eds., Proceedings of the Ninth International Symposium on River Sedimentation: Beijing, China, Tsinghua University Press, p. 154-161.

Meade, R.H., and Moody, J.A., 2010, Causes for the decline of suspended-sediment discharge in the Mississippi River system, 1940-2007: Hydrological Processes, v. 24, p. 35-49.

Meade, R.H., and Parker, R.S., 1985, Sediment in rivers of the United States, National Water Data Summary 1984: U.S. Geological Survey Water-Supply Paper 2275, p. 49-60.

Meade, R.H., Yuzyk, T.R., and Day, T.J., 1990, Movement and storage of sediment in rivers of the United States and Canada, in Wolman, G., and Riggs, H.C. eds., Surface Water Hydrology - The geology of North America, ,v. O-1, M: Geological Society of America, Boulder, Colo., p. 255-280.

Missouri Basin Inter-Agency Committee, 1969, Comprehensive framework study: Missouri River Basin, v. 1, Washington, D.C., U.S. Government Printing Office.

Mossa, J., 1996, Sediment dynamics in the lowermost Mississippi River: Engineering Geology, v. 45, p. 457-479.

Moulton, G., ed., 1986, The Journals of the Lewis \& Clark Expedition: v. 2, Lincoln, Nebraska, University of Nebraska Press, $612 \mathrm{p}$.

National Research Council, 2011, Missouri River planningRecognizing and incorporating sediment management: Washington D.C., National Academies Press, 152 p.

Nittrouer, J.A., Allison, M.A., and Campanella, R., 2008, Bedform transport rates for the lowermost Mississippi River: Journal of Ecophysical Research, Earth Surface, v. 113, $16 \mathrm{p}$.

O'Brien, W.P., Rathbun, M.Y., O'Bannon, P., and Whitacre, C., 1992, Gateways to commerce $\_$The U.S. Army Corps of Engineers' 9-foot channel project on the upper Mississippi River: U.S. National Park Service, Rocky Mountain Region, $238 \mathrm{p}$. 
Perry, C.A., 1994, Effects of reservoirs on flood discharges in the Kansas and Missouri River Basins, 1993: U.S. Geological Survey Circular 1120-E, 20 p.

Porterfield G., 1977, Computation of fluvial-sediment discharge: Techniques of Water-Resources Investigations of the U.S. Geological Survey, book 3, chap. C3, 66 p.

Pyron, M., and Neumann, K., 2008, Hydrologic alterations in the Wabash River Watershed, USA: River Research and Applications, v. 24, p. 1,175-1,184.

Rasmussen, P.P., Gray, J.R., Glysson, G.D., and Ziegler, A.C., 2009, Guidelines and procedures for computing time-series suspended sediment concentrations and loads from instream turbidity-sensor and streamflow data: U.S. Geological Survey Techniques and Methods, book 3, chap. C4, $54 \mathrm{p}$.

Rebich, R., and Demcheck, D.K., 2007, Trends in nutrient and sediment concentrations and loads in major river basins of the south-central United States, 1993-2004: U.S. Geological Survey Scientific Investigations Report 2007-5090, $112 \mathrm{p}$.

Runkel, R.L., Crawford, C.G., and Cohn, T.A., 2004, Load Estimator (LOADEST) - A FORTRAN program for estimating constituent loads in streams and rivers: U.S. Geological Survey Techniques and Methods, book 4, chap. A5, 69 p.

Sen, P.K., 1968, Estimates of the regression coefficient based on Kendall's Tau: Journal of the American Statistical Association, v. 63, p. 1,379-1,389.

Sidle, J.G., and Faanes, C.A., 1997, Platte River ecosystem resources and management, with emphasis on the Big Bend reach in Nebraska: U.S. Fish and Wildlife Service, Grand Island, Nebraska, Northern Prairie Wildlife Research Center, accessed December 2010, at http://www.npwrc.usgs.gov/ resource/habitat/plrivmgt/index.htm.

Smith, L.M., and Winkley, B.R., 1996, The response of the lower Mississippi River to river engineering: Engineering Geology, v. 45, p. 433-455.

Sprague, L.A., Clark, M.L., Rus, D.L., Zelt, R.B., Flynn, J.L., and Davis, J.V., 2006, Nutrient and Suspended-Sediment Trends in the Missouri River Basin 1993-2003: U.S. Geological Survey Scientific Investigations Report 2006-5231, $80 \mathrm{p}$.

Trimble, S.W., 1983, A sediment budget for Coon Creek Basin in the Driftless Area, Wisconsin, 1853-1977: American Journal of Science, v. 283, p. 454-474.
Tuttle, J.R., and Combe, A.J., 1981, Flow regime and sediment load affected by alterations of the Mississippi River in Cross, R.D., and Williams, D., eds., Proceedings of the National Symposium on Freshwater inflow to Estuaries: Fish and Wildlife Service, Office of Biological Services report FWS/OBS-81/04, p. 334-348.

U.S. Army Corps of Engineers, 1930, Sediment investigations of the Mississippi River and its tributaries prior to 1930 , paper H: U.S. Army Corps of Engineers Waterways Experiment Station, Vicksburg, Miss.

U.S. Army Corps of Engineers, 1976, Suspended sediment in the Missouri River-Daily record for water years 19701974, Kansas City, Missouri: U.S. Army Corps of Engineers, Missouri River Division, 201 p.

U.S. Army Corps of Engineers, 2004, Missouri River stage trends, RCC Technical Report A-04: U.S. Army Corps of Engineers, Northwest Division, Reservoir Control Center, Omaha, Nebraska, 40 p.

U.S. Army Corps of Engineers, 2009a, Missouri River bed degradation reconnaissance study: U.S. Army Corps of Engineers Kansas City District, 67 p., accessed June 2010, at http://www.nwk.usace.army.mil/projects/ MoRiverDegradation/Documents/MORiverBedDegrada tionReconStudy.pdf.

U.S. Army Corps of Engineers, 2009b, Ohio River Basin Comprehensive Reconnaissance Report, Great Lakes and Ohio River Division, 211 p., accessed August 2010, at http://www.ohioriverbasin.org/pdfs/ORBStudy.pdf.

U.S. Department of Agriculture, Natural Resources Conservation Service, 2009, Phase II sedimentation assessment for the upper Missouri River Basin: U.S. Department of Agriculture Assessment Report, 51 p., accessed February 2010, at http://www.msaconline.com/Missouri\%20River $\% 20$ Phase\%20II\%20\%20Report.pdf.

U.S. Fish and Wildlife Service, 2003, Amendment to the 2000 Biological Opinion on the Operation of the Missouri River Main Stem Reservoir System, Operation and Maintenance of the Missouri River Bank Stabilization and Navigation Project, and Operation of the Kansas River Reservoir System: U.S. Fish and Wildlife Service, 308 p., accessed December 2010, at http://www.nwd-mr.usace.army.mil/ mmanual/FinalBO2003.pdf.

van Heerden, I., and K. DeRouen, K., Jr., 1997, Implementing a barrier island and barrier shoreline restoration programthe state of Louisiana's perspective: Journal of Coastal Research, v. 13, p. 679-685.

West Consultants Inc., 2000, Upper Mississippi River and Illinois Waterway Cumulative Effects Study, Volume 1Geomorphic assessment, Final Report: Contract DACW2597-R-0012 and ENV Report 40-1, 244 p. 
White, D., Johnston, K., and Miller, M., 2005, Ohio River basin, in Benke, A.C., and Cushing, C.E., eds., Rivers of North America: Burlington, Vt., Elsevier Academic Press, p. $375-424$.

Zelt, R.B., Boughton, G., Miller, K.A., Mason, J.P., and Gianakos, L.M., 1999, Environmental setting of the Yellowstone River Basin, Montana, North Dakota, and Wyoming: U.S. Geological Survey Water-Resources Investigations Report 98-4269, $113 \mathrm{p}$. 
Publishing support provided by:

Rolla Publishing Service Center

For more information concerning this publication, contact: Director, USGS Missouri Water Science Center

1400 Independence Road

Rolla, M0 65401

(573) 308-3667

Or visit the Missouri Water Science Center Web site at: http://mo.water.usgs.gov 
